
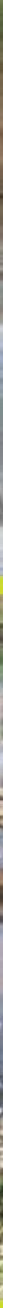

AGRICULTURE, NATURAL RESOURCES, AND RURAL DEVELOPMENT SECTOR ASSESSMENT, STRATEGY, AND

ROAD MAP

LAO PEOPLE'S DEMOCRATIC REPUBLIC

DECEMBER 2018 


\section{AGRICULTURE, NATURAL RESOURCES, AND RURAL DEVELOPMENT SECTOR ASSESSMENT, STRATEGY, AND ROAD MAP}

LAO PEOPLE'S DEMOCRATIC REPUBLIC

DECEMBER 2018 
(C) 2018 Asian Development Bank 6 ADB Avenue, Mandaluyong City, 1550 Metro Manila, Philippines

Tel +632632 4444; Fax +6326362444

www.adb.org

Some rights reserved. Published in 2018.

ISBN 978-92-9261-464-5 (print), 978-92-9261-465-2 (electronic)

Publication Stock No. TCS $189785-2$

DOI: http://dx.doi.org/10.22617/TCS189785-2

The views expressed in this publication are those of the authors and do not necessarily reflect the views and policies of the Asian Development Bank (ADB) or its Board of Governors or the governments they represent.

ADB does not guarantee the accuracy of the data included in this publication and accepts no responsibility for any consequence of their use. The mention of specific companies or products of manufacturers does not imply that they are endorsed or recommended by ADB in preference to others of a similar nature that are not mentioned.

By making any designation of or reference to a particular territory or geographic area, or by using the term "country" in this document, $A D B$ does not intend to make any judgments as to the legal or other status of any territory or area.

This work is available under the Creative Commons Attribution 3.0 IGO license (CC BY 3.0 IGO)

https://creativecommons.org/licenses/by/3.o/igo/. By using the content of this publication, you agree to be bound by the terms of this license. For attribution, translations, adaptations, and permissions, please read the provisions and terms of use at https://www.adb.org/terms-use\#openaccess.

This CC license does not apply to non-ADB copyright materials in this publication. If the material is attributed to another source, please contact the copyright owner or publisher of that source for permission to reproduce it. $\mathrm{ADB}$ cannot be held liable for any claims that arise as a result of your use of the material.

Please contact pubsmarketing@adb.org if you have questions or comments with respect to content, or if you wish to obtain copyright permission for your intended use that does not fall within these terms, or for permission to use the ADB logo.

Notes:

In this publication, “\$” refers to United States dollars.

ADB recognizes "Laos" as the Lao Democratic People's Republic.

On the cover: ADB's support for rural infrastructure development has helped improved road conditions in the Lao

People's Democratic Republic (photos from LAO 42203: Additional Financing of Northern Rural Infrastructure

Development Sector Project).

Corrigenda to ADB publications may be found at http://www.adb.org/publications/corrigenda. 


\section{Contents}

Tables and Figures

Currency Equivalents

I. Sector Assessment: Context and Strategic Issues

A. Introduction

B. Overall Sector Context

C. Core Sector Issues, Causes, and Effects

II. Sector Strategy
A. Government Sector Strategy, Policy, and Plans
B. ADB's Sector Support Program and Experience
C. Other Development Partner Support
D. ADB's Sector Forward Strategy

III. Sector Road Map and Results Framework

\section{APPENDIX}

Sector Problem Analysis 


\section{Tables and Figures}

\section{Tables}

1 Growth in Rice Area and Production in the Lao PDR versus Neighboring and Nearby Southeast Asian Countries (2005-2014)

2 Growth in the Area and Production of Major Crops Other Than Rice (2005-2014) 5

3 Growth in the Population of Major Livestock (2005-2014) 6

4 Poverty Incidence, from 1992-1993 to 2012-2013 7

5 Number of Students in Agriculture Courses in State Schools (2016-2020) 14

6 Success Rating of Agriculture, Natural Resources, and Rural Development 21 Completed Projects Approved since 2000

7 Ongoing Agriculture, Natural Resources, and Rural Development 23 and Related Projects

8 Success Rating of Recent Agriculture, Natural Resources, and Rural Development Completed Technical Assistance Projects

9 Current Agriculture, Natural Resources, and Rural Development Projects in the Country Operations Business Plan

Figures

A1 Agriculture, Natural Resources, and Rural Development Problem Tree

A2 Agriculture, Natural Resources, and Rural Development Objective Tree 


\section{Currency Equivalents}

(as of 15 August 2018)

$$
\begin{aligned}
\text { Currency Unit } & -\operatorname{Kip}(\mathrm{KN}) \\
\mathrm{KN} 1.0 & =\$ 0.000118 \\
\$ 1.00 & =\mathrm{KN} 8,464.95
\end{aligned}
$$




\section{Abbreviations}

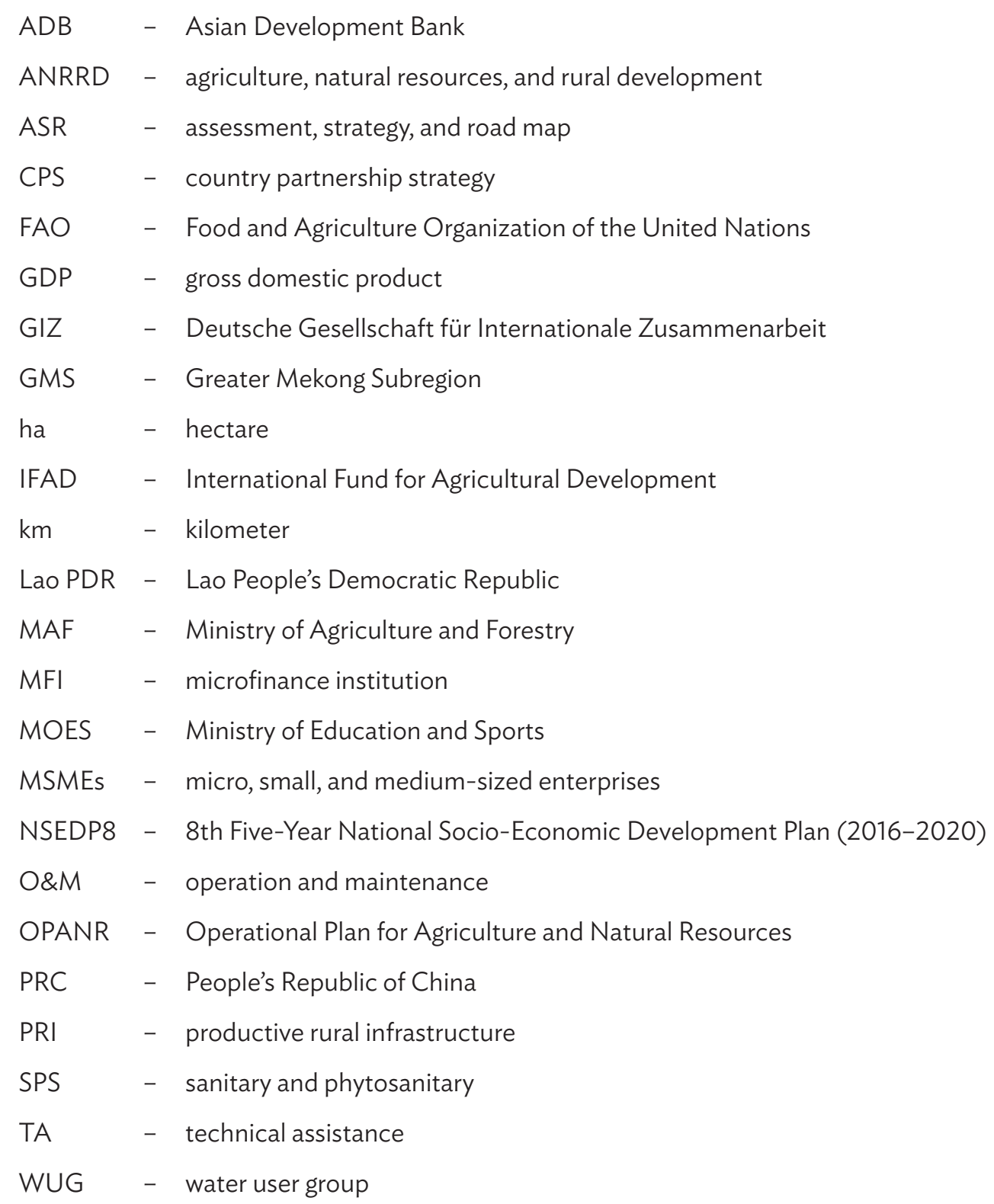




\section{Sector Assessment: Context and Strategic Issues}

Agriculture has a potential for significant growth and will continue to have a major and inclusive role in the Lao People's Democratic Republic (PDR) economy. The Asian Development Bank $(A D B)$ remains committed to supporting modern sustainable agricultural development.

\section{A. Introduction}

1. This sector assessment, strategy, and road map (ASR) explains the evaluation and strategic investment priorities of the Government of the Lao PDR and ADB in the agriculture, natural resources, and rural development (ANRRD) sector. The ASR highlights sector performance, priority development constraints, government plans and strategy, past ADB support and experience, other development partner support, and the future ADB sector strategy. It informs ADB's country partnership strategy (CPS) for the Lao PDR and is updated as strategic developments and program changes occur. It helps provide sector background information for ADB's investment and technical assistance (TA) operations.

\section{B. Overall Sector Context}

2. The Lao PDR is in the center of the Southeast Asian mainland bordering Cambodia, Myanmar, the People's Republic of China (PRC), Thailand, and Viet Nam. It is a long, narrow country, stretching about 1,700 kilometers $(\mathrm{km})$ from north to south but only about 100 $\mathrm{km}$ across at its narrowest width. The country's low population of about 6.5 million in 2017 and mountainous topography limit expansion of agricultural development, with only about $10 \%$ of the country's land area used for agriculture. ${ }^{2}$ Moreover, agricultural land is dispersed, especially in the northern mountains. About $50 \%$ of the arable land supports annual crops, the balance being used for perennial crops (such as coffee) or pastures and grasslands. Only a few areas along the Mekong River and its tributaries have large contiguous cropped land, notably in the Vientiane plain, and in central and southern riverine plains in Sayabouri, Khammouane, Savannakhet, and Champasak provinces. ${ }^{3}$

ADB. 2017. Country Partnership Strategy: Lao People's Democratic Republic, 2017-2020-More Inclusive and Sustainable Economic Growth. Manila.

2 Government of the Lao PDR, Lao Statistics Bureau. 2015. Statistical Yearbook 2014. Vientiane. The Ministry of Agriculture and Forestry (MAF) considers the agricultural area to cover about 4.5 million hectares (ha), of which 3.8 million ha is potentially suitable for cultivation. However, by international definitions, only about 1.5 million ha is classified arable.

3 Food and Agriculture Organization of the United Nations (FAO). 2016. FAOSTAT: Lao Peoples' Democratic Republic. Rome. 
3. Nonagricultural land areas are either forested (around 11 million hectares [ha] to various degrees, from fully mature primary forest to sparse secondary forest); urban; or rough mountainous terrain. The Lao PDR is still relatively abundant in biodiversity and wildlife, although there is continuous encroachment on its forest and wildlife resources from poaching, mining, hydropower development, shifting cultivation, and commercial plantations. As much as $21 \%$ of the land area is estimated to be under concessions and leases, with the majority of this area being for mining-related activities. It is estimated that 446,249 ha are used for plantations.

4. Rice is the major crop for the Lao PDR, accounting for $50 \%$ of national agricultural output. About 960,000 ha are in wet season rice cultivation and grown in large part for subsistence. Limited irrigation coverage results in only $4 \%$ of the wet season area being cultivated in dry season. Lowland paddy production accounts for $75 \%$ of the rice-growing area and is largely focused in the four provinces-Xayaboury, Khammouane, Savannakhet, and Champasak. Upland rice predominates in mountainous areas, especially in the northern region. Other major crops include maize, cassava, banana, and coffee, which are grown for both subsistence and commercial purposes. Livestock production, which accounts for $18 \%$ of agriculture gross domestic product (GDP), contributes a significant amount to household and national income with most farm families owning some livestock to be used as a form of household savings or for commercial sales. ${ }^{4}$

5. Water is seasonally available and usually sufficiently abundant in the wet season for a monsoon rice crop. However, in the dry season, irrigation is needed to ensure crop production. Pumped irrigation suffers from high operating and capital costs that are often nonviable in low-productivity farming systems. Only about 350,000 ha of land is provided with any irrigation, which is primarily for supplementary irrigation in the wet season. Only $38 \%$ of the irrigated areas produce dry season crops.

6. The key challenge to success in all types of irrigation is the provision of adequate operation and maintenance (O\&M). Irrigation schemes must provide producers with a reliable water supply if these producers are to continue to invest in the productivity of their cropping systems in response to market demand. Sustainable irrigation requires meeting significant capital costs, high operating costs, and a high degree of community cohesion. Failure to build schemes that minimize the O\&M burden and build up the capacities needed to meet O\&M requirements, especially in the water user groups (WUGs), is a chronic cause of suboptimal scheme performance or even failure in the Lao PDR.

7. Within these natural limitations, the Lao PDR remains an agrarian economy with most of the population dependent on agriculture. During 2008-2013, the total economically active agricultural population remained relatively unchanged, with over $70 \%$ of the population active to some extent in the ANRRD sector and about 783,000 or $50 \%$ of all households still mainly or partly subsistence farmers. Moreover, $61 \%$ of all hours worked nationally are in agriculture. $^{5}$

8. While most households depend on agriculture, the role of agriculture in the household has declined substantially with the increased connectivity between rural districts

ADB. 2017b. Lao PDR: Accelerating Structural Transformation for Inclusive Growth: Country Diagnostic Study. Manila. United States Agency for International Development. 2013. Lao People's Democratic Republic: RATE Country Summary: USAID Maximizing Agricultural Revenue through Knowledge, Enterprise Development and Trade (MARKET) Project. 
and the emerging urban population and with neighboring countries. Many rural households generate only $30 \%-40 \%$ of their income from agriculture, with the remainder coming from off-farm sources including casual labor, paid employment, government salaries, and remittances from extended family members. In general, households with a higher proportion of income from agriculture are poorer especially if they predominantly grow wet season or irrigated rice.

9. With increased transport network connectivity, more producers are accessing regional markets in (i) Thailand in the south and center where contract farming is expanding and there is a demand for cool-season vegetables from the Bolovens Plateau; (ii) the PRC in the northern region to meet that country's demand for agricultural products, again with increasing levels of contract farming; and (iii) Viet Nam on the eastern border. Increasingly, these transport corridors are also providing linkages to the more populous eastern side of the Lao PDR, which has the greatest agriculture output.

10. The ANRRD sector is characterized by (i) geographically scattered production due to the country's topography and weak linkages to urban populations and regional markets, (ii) a production base heavily targeted toward rice consequently limits diversification of output that is also constrained by limited access to irrigation in the dry season, and (iii) a heavy dependence of the population on ANRRD as a source of employment as well as food. The country's forest resources and unique biodiversity and ecological conditions that underpin ecosystem services make environmental conservation and sustainable land use issues of importance.

11. The ANRRD sector is characterized by the "missing middle" (lack of downstream enterprises), reflecting the relatively narrow range of productive outputs that involve small, fragmented production volumes, and extremely short mostly local and seasonal market chains, and the high cost of freight. The missing middle reflects the commoditization of commercial agriculture through external investment and control where regional enterprises directly contract land and manage the output from farm to border.

12. The largest traded crops, other than rice, are maize production for animal feed; banana, citrus, and watermelon; cereal production for Job's tears; and livestock are sold to Thailand, the PRC, and Viet Nam. While these crops are often extensive, they provide substantial benefits to producers but little value added within the Lao PDR. Further, many crops are associated with significant environmental and social costs in the form of land conversion, excessive and inappropriate use and handling of agrochemicals, poor disposal of wastes including plastic that is either burned or buried often in cropland, and the transmission of infectious livestock disease through the movement across provinces and borders.

13. Many small producers report market risk as a far more significant factor than the climate and production risks they face. While market demand for crop and livestock products is increasing (and this is expected to continue), product market chains are dominated by small operators (mostly low-volume and low-margin traders) connecting with small domestic and neighboring markets such as Thailand for maize; Japan and Taipei,China for Job's tears; the PRC for maocha (forest) tea, green soybeans, and livestock; Viet Nam for livestock, vegetables, and animal feed raw materials; and globally for coffee production. 
14. These supply chains are more cooperative than contractual, using past relationships, while many are simply opportunistic. The agribusiness sector outside the largest centers is sparse. It has few formal agribusiness associations with little representation in chambers of commerce. Larger agri-enterprises serving the sector are the exception and are very few.

15. Significant institutional constraints persist with the public sector inadequately skilled in supporting the production and marketing of commercial agricultural products. In the provinces, agribusiness sector growth and development need direction to capitalize on current and emerging market opportunities. However, the required coordination is currently insufficient from the provincial agencies.

16. Development partner attempts at supporting rural enterprises have been less than successful. ${ }^{6}$ Past reliance on the public sector extension services or technical agencies was found to be wanting and is mostly nonfunctional without external input due to staff, budgetary, and institutional limitations. The promotion of farmer production groups by the government has not provided sustained benefits to the members, while farmer-to-farmer extension and farmto-market linkages have been limited to small scales. Private sector service provision models have struggled to establish and sustain staff and services without external support.

17. From 2010 to 2014, relative to the national economy, the ANRRD sector has grown at a slower rate. The overall economy expanded to 7\%-8\% annually, while ANRRD growth remained steady at around 3.7\%. ANRRD contribution to the national economy fell from $33 \%$ to $27 \%$ of GDP.

18. The slower sector growth does not give the full picture. The figures are derived from the Lao Statistics Bureau, which divides the agriculture sector into three categories: (i) crops, animal raising, and hunting; (ii) forestry; and (iii) fishing. If these are disaggregated, the first category, which makes $85 \%$ of the agriculture GDP and is most important to sector development from a socioeconomic point of view, shows annual growth of around $5 \%$, which is consistent with documented increases in production. ${ }^{7}$ The $5 \%$ growth rate disguises vastly different rates for (i) subsistence households mostly in upper watersheds with high levels of poverty, (ii) households that are intensifying production and selling surpluses in local markets, and (iii) commercial agriculture where producers are directly linked with regional and international markets with a profit objective.

19. Available statistics indicate substantially higher growth grates in rice and other diversified crops. As shown in Table 1, both the area and production of rice have been increasing. During 2005-2014, the area planted in rice increased by $30 \%$, while production increased by $56 \% .^{8}$ The Lao PDR has surpassed self-sufficiency in rice for the last decade.

World Bank. 2014. Lao PDR - Small and Medium Enterprise Access to Finance Project. Washington, D.C. The project offers credit to small and medium-sized enterprises but has had a minimal uptake with disbursement of approximately 20\%. The overall low agriculture GDP may be attributed to growth declines in forestry and stagnant growth in fisheries. ADB's 2017 country diagnostic study (footnote 4) suggests the accuracy and dependability of government statistics (which are also used by FAO for their statistics base for the country) may be somewhat weak, but in the absence of more precise figures, these have been used in this analysis. 
Table 1: Growth in Rice Area and Production in the Lao PDR versus Neighboring and Nearby Southeast Asian Countries (2005-2014)

\begin{tabular}{lcccccc} 
& $\begin{array}{c}\text { Area of Rice } \\
\text { in 2005 } \\
\text { (OOO ha) }\end{array}$ & $\begin{array}{c}\text { Area of Rice } \\
\text { in 2014 } \\
(000 \text { ha) }\end{array}$ & $\begin{array}{c}\text { Increase } \\
(\%)\end{array}$ & $\begin{array}{c}\text { Production of } \\
\text { Rice in 2005 } \\
(000 \mathrm{t})\end{array}$ & $\begin{array}{c}\text { Production of } \\
\text { Rice in 2014 } \\
(000 \mathrm{t})\end{array}$ & $\begin{array}{c}\text { Increase } \\
(\%)\end{array}$ \\
\hline Lao PDR & 736 & 958 & 30 & 2,568 & 4,002 & 56 \\
\hline Cambodia & 2,414 & 2,856 & 18 & 5,986 & 9,324 & 56 \\
\hline Indonesia & 11,839 & 13,797 & 17 & 54,151 & 70,846 & 31 \\
\hline Myanmar & 7,384 & 6,790 & $(8)$ & 27,683 & 26,423 & $(5)$ \\
\hline Philippines & 4,070 & 4,739 & 16 & 14,603 & 18,967 & 30 \\
\hline Thailand & 10,224 & 10,664 & 4 & 30,291 & 32,620 & 8 \\
\hline Viet Nam & 7,329 & 7,816 & 7 & 35,832 & 44,974 & 26 \\
\hline
\end{tabular}

()$=$ negative, ha $=$ hectare, Lao PDR = Lao People's Democratic Republic, $t=$ metric ton .

Source: Food and Agriculture Organization of the United Nations. FAOSTAT. http://www.fao.org/faostat/ en/\#data/QA (accessed 1 November 2017).

20. In the case of crops (other than rice), maize, coffee, and banana production increased around threefold; cassava production increased a phenomenal 3,100\%; 9 and fresh vegetable production increased by $108 \%$ (Table 2). Most of the increases for these crops were geared toward exports to the PRC, Thailand, and Viet Nam where with improving transport connections, are becoming increasingly viable markets. Since the percent increase in production is higher than the percent increase in area, these production increases were in large part a result of improved practices rather than simply an area increase.

Table 2: Growth in the Area and Production of Major Crops Other Than Rice (2005-2014)

\begin{tabular}{|c|c|c|c|c|c|c|}
\hline Crop & $\begin{array}{c}\text { Area in } 2005 \\
\text { ('000 ha) }\end{array}$ & $\begin{array}{c}\text { Area in } \\
2014 \\
\text { ('000 ha) }\end{array}$ & $\begin{array}{c}\text { Increase } \\
(\%)\end{array}$ & $\begin{array}{l}\text { Production in } \\
2005 \\
(000 t)\end{array}$ & $\begin{array}{l}\text { Production in } \\
2014 \\
(000 t)\end{array}$ & $\begin{array}{c}\text { Increase } \\
(\%)\end{array}$ \\
\hline Maize & 86 & 243 & 183 & 373 & 1,412 & 279 \\
\hline Cassava & 7 & 60 & 757 & 51 & 1,630 & 3,096 \\
\hline Coffee & 43 & 70 & 63 & 25 & 114 & 356 \\
\hline Bananas & 10 & 23 & 130 & 148 & 506 & 242 \\
\hline $\begin{array}{l}\text { Fresh } \\
\text { vegetables }\end{array}$ & 86 & 161 & 87 & 744 & 1,550 & 108 \\
\hline
\end{tabular}

ha $=$ hectare, $\mathrm{t}=$ metric ton .

Source: Food and Agriculture Organization of the United Nations. FAOSTAT. http://www.fao.org/faostat/ en/\#data/QA (accessed 1 November 2017).

\footnotetext{
The figures for cassava may be inaccurate. The data show a much larger area and production from 2006 rather than 16,880 ha and 174,490 tons, which would indicate a still impressive growth in area of $260 \%$ and a growth in production of $830 \%$.
} 
21. There are opportunities in livestock with the Lao PDR neighboring countries, especially the PRC and Viet Nam, with high rates of economic growth, increasing prosperity, and growing demand for protein, particularly livestock products. Moreover, further land conversion opportunity exists in the Lao PDR to expand both cash crop and livestock production. The livestock sector growth is especially rapid. Table 3 illustrates that there was significant growth notably for pigs, cattle, and goats.

Table 3: Growth in the Population of Major Livestock (2005-2014)

\begin{tabular}{lccc} 
Livestock & $\begin{array}{c}\text { Population in } 2005 \\
(\text { (O) head) }\end{array}$ & $\begin{array}{c}\text { Population in 2014 } \\
(000 \text { head) }\end{array}$ & $\begin{array}{c}\text { Increase } \\
(\%)\end{array}$ \\
\hline Pigs & 1,826 & 3,122 & 71 \\
Goats & 190 & 481 & 64 \\
Chickens & 19,801 & 32,408 & 39 \\
Cattle & 1,272 & 1,766 & 2 \\
\hline Buffalo & 1,125 & 1,153 & \\
\hline
\end{tabular}

Source: Food and Agriculture Organization of the United Nations. FAOSTAT. http://www.fao.org/faostat/ en/\#data/QA (accessed 1 November 2017).

22. Livestock are particularly important in the more poverty-prone northern provinces, where there is less land available for cropping due to the mountainous terrain. Some $89 \%$ of farm households own one or more types of livestock, and where possible, many households will have fishponds. Smallholder farmers dominate livestock production, accounting for approximately $95 \%$ of national herd. The feeding of animals includes (i) fallow cropland; (ii) communal areas along roads and rivers, and areas around fields and villages; (iii) dedicated grazing land; (iv) secondary forests; and (v) other uncropped communal lands. Crop byproducts such as rice straw are also fed to ruminants.

23. Commercial livestock production has developed around major towns and cities such as Vientiane, supplying meat, eggs, and milk to the urban population. Significant crossborder livestock trade is expanding in the PRC and Viet Nam with further potential growth if reproductive and survival rates continue to improve, ensuring livestock health and easing the sale and transport of stock. Current livestock trade is significantly underreported with crossborder movement of livestock mostly avoiding international border gates.

24. Although available statistics lack a high degree of precision, the picture of growth and productivity provides a reason for optimism for the future of the ANRRD sector and the rural economy. These production increases, often aimed at export markets, demonstrate that, with market access, potential exists within the ANRRD sector to provide commercially oriented earnings and to make the ANRRD sector a source of inclusive economic growth. Consequently, the ANRRD sector will continue to play a major role in the Lao PDR economy as it is currently the source of income, employment, and food for most of the country's population despite the rapid pace of development of other sectors. 
25. ANRRD provides an important safety net for workers dropping out of or displaced from other sectors. It is unlikely the industrial or service sectors can grow sufficiently in the next decade to employ most of the current agriculture workers, especially in the more remote regions of the country. Growth in the service sector is also dependent on ANRRD through such interactions as trade, transport, processing, and marketing.

26. Since 1996, economic growth has helped halve the national poverty rate (from $46 \%$ to $23 \%$ by 2013). Because of the predominance of agriculture in the economy and most of the country's poor were in rural areas, ANRRD sector growth has contributed to this accomplishment. The country's declining poverty levels are shown in Table 4.

Table 4: Poverty Incidence, from 1992-1993 to 2012-2013 (\%)

\begin{tabular}{lccccc} 
& $1992-1993$ & $1997-1998$ & $2002-2003$ & $2007-2008$ & $2012-2013$ \\
Rural & 51.8 & 42.5 & 37.6 & 31.7 & 28.6 \\
Urban & 26.5 & 22.1 & 19.7 & 17.4 & 10.0 \\
Vientiane & 33.6 & 13.5 & 16.7 & 15.2 & 5.9 \\
North & 51.6 & 47.3 & 37.9 & 32.5 & 25.8 \\
Central & 45.0 & 39.4 & 35.4 & 29.8 & 23.3 \\
South & 45.7 & 39.8 & 32.6 & 22.8 & 29.2 \\
National & $\mathbf{4 6 . 0}$ & $\mathbf{3 9 . 1}$ & $\mathbf{3 3 . 5}$ & $\mathbf{2 7 . 6}$ & $\mathbf{2 3 . 2}$ \\
\hline
\end{tabular}

Source: P. Warr, S. Rasphone, and J. Menon. 2015. Two Decades of Rising Inequality and Declining Poverty in the Lao People's Democratic Republic. ADB Economics Working Paper Series. No. 461. Manila: ADB.

27. The pockets of poverty that still exist (especially in upland areas and among ethnic minority groups at 39\%) are mostly rural based. Poverty rate averages $28 \%$ in rural areas. Income inequality is increasing-while average gross household agriculture income was $\$ 1,707$ per year in 2014 -and $50 \%$ of rural households remain subsistence farmers with incomes below $\$ 300$ per year. Economic growth has benefited people in the lowlands more than upland ethnic minority groups. ${ }^{10}$

28. The characteristics that tend to make people poor are not uniform. ${ }^{11}$ Policies need to be tailor-made to meet the specific needs of distinct groups of the poor and near-poor (broadly defined as the bottom 40\%) in the Lao PDR. Four subgroups are identified using data collected in the Lao PDR's expenditure and consumption survey (the first two are relevant to the ANRRD sector):

(i) Households mainly involved in low-productivity farming in remote areas with low educational attainment. These households are mainly constrained by their poor connectivity and low levels of education, both of which inhibit their

10 P. Warr, S. Rasphone, and J. Menon. 2015. Two Decades of Rising Inequality and Declining Poverty in the Lao People's Democratic Republic. ADB Economics Working Paper Series. No. 461. Manila: ADB.

11 World Bank Group. 2017. Lao Poverty Policy Brief: Taxonomy of the Poor and Its Usefulness in Policy Design. Vientiane. 
participation in the broader economy. They require increased infrastructure investments and more effective delivery of social services tailored to the unique challenges in remote areas, especially to raise their educational attainment.

(ii) Households with low agricultural productivity but able to produce greater surpluses, with low-moderate education but still unable to transition into nonfarm employment. Having access to larger tracts of land, these households find themselves poor because of low margins in agriculture. Policies that make agriculture more profitable, such as promoting value-chain integration and lowering marketing costs, would be the most beneficial for these households. Increasing educational attainment would also facilitate their transition into nonfarm employment.

(iii) Households mainly working in low-productivity nonfarm jobs in the informal sector, usually in more urbanized areas, with moderate education. The main constraint for households in this group is in the low productivity of their nonfarm work. With moderate education, these households would benefit from policies that foster the creation of better jobs in the manufacturing and services sectors, and enable them to complete their transition into productive nonfarm employment.

(iv) Households with recent exposure to a health shock. Improving the national health insurance model for households in the rural and informal sectors, for whom employer-based insurance is not an option, would help to prevent households from falling into poverty and serve to reduce their vulnerability.

29. The contribution of women to ANRRD is crucial. Women make up 54\% of the rural workforce, but have less access to credit and technology, and work on average 9 hours per week more than men. A woman's workload is typically heaviest in upland ethnic minority group settlement areas. If women have access to land, they will often engage in commercial production to supplement household income. There are potential opportunities for women in rural areas and sources of inclusive income growth, especially if access to technology, credit, and markets is provided. This makes the ANRRD sector important in terms of fostering gender equity.

30. Food security is a major element within the national agricultural strategy primarily in response to the impacts of inadequate nutrition in the form of stunting, wasting, and child mortality. Most of the Lao PDR population is food secure, but the underlying issue relates to the adequacy of diets and dietary diversity for adolescent women, especially during pregnancy, and for infant and young children feeding during the first 3 years of age. The outstanding challenge is to provide the diversity of diets including a wider range of protein sources and fresh fruits and vegetables for priority target groups.

31. Nutrition-sensitive agriculture is a key element in the National Nutrition Strategy (2016-2025) that was developed in response to the "very high" incidence of stunting (equivalent to over $40 \%$ of children under 5 years). The 2012 rate was $44 \%$, the equivalent of over 400,000 children. The economic cost of undernutrition to the Lao PDR economy was estimated to be $2.4 \%$ of GDP. ${ }^{12}$ Based on the World Health Organization nutrition target,

12 Government of the Lao PDR, Ministry of Health and Lao Statistics Bureau. 2012. Lao Social Indicator Survey 2011-12. Vientiane. 
the prevalence of stunting of children under 5 years in the Lao PDR is targeted to decline to $27.4 \%$ by 2025 . The latest data indicate significant reductions in the incidence of stunting. However, the rate of progress in reducing wasting has been far slower. ${ }^{13}$

32. Stunting is far more prevalent in rural communities (double that of urban levels) and is closely correlated with the poverty status. ${ }^{14}$ Other related undernutrition issues include (i) micronutrients (especially vitamin A), and (ii) vulnerability to wasting with incidence rates as high as $20 \%$ in some northern provinces.

33. The following are key parameters in understanding undernutrition in the Lao PDR: (i) People are vulnerable to shocks, especially if access to land is reduced or lost, with women being highly affected; (ii) Access to water, sanitation, and hygiene facilities is lacking, which leads to frequent and recurring infections, reducing the body's ability to absorb nutrients; (iii) There is a need for greater empowerment of women-25\% of teenage girls are married, while $37 \%$ of women aged $20-40$ have given birth before the age of 18; (iv) Women are often overworked, less educated, and lack the vital nutrients throughout their pregnancy and after birth; ( $v$ ) Adolescent pregnancy rates are high, with adolescent females dropping out of school with little childcare support and many infants failing to get the calories and nutrients they need after 6 months; and (vi) Health care and outreach services are weak, especially in rural districts. ${ }^{15}$

34. The government's strategy is built on a convergence plan to link multiple sectors and levels of administration through a social behavior change communication strategy that targets infant and young child feeding; maternal nutrition and dietary diversity; water, sanitation, and hygiene services; and nutrition-sensitive agriculture that increases the food quality and access to more diverse protein and food crop choices. ${ }^{16}$ The focus of nutritionsensitive agriculture is dry season and non-rice wet season diversification for crops, and the diversification of protein sources through fish and animal products.

35. The conservation of the country's forested area is vital for biodiversity and natural environmental health. The Food and Agriculture Organization of the United Nations (FAO) Global Forest Resources Assessment indicates that the forest area in 2010 was almost 15.8 million ha (some $67 \%$ of the total land area of the country). ${ }^{17}$ WWF identifies the Lao PDR as among the 200 global priority eco-regions for biodiversity conservation. ${ }^{18}$ Moreover, nontimber forest products are often an important source of food security for many subsistence farming households.

36. However, the Lao PDR's rich biodiversity is under pressure and is in decline. There is inadequate regulation, oversight, and supervision of natural resource exploitation and

13 Government of the Lao PDR Lao Statistics Bureau. 2018. Lao Social Indicator Survey II, 2017, Survey Findings Report. Vientiane.

14 In 2015, 61\% of children under 5 years in the poorest $20 \%$ of the population were stunted compared with $20 \%$ in the highest wealth group.

15 European Union. 2015. We Can Overcome Undernutrition: Lao PDR Case Study. Brussels.

16 Government of the Lao PDR, Ministry of Planning and Investment. 2016. 8th Five-Year National Socio-Economic Development Plan (2016-2020). Vientiane.

17 The REDD Desk. Laos. Statistics. http://theredddesk.org/countries/laos/statistics (updated [accessed] 2018).

18 ADB. 2010. Greater Mekong Subregion Biodiversity Conservation Corridors Feasibility Report. Manila; ADB. 2010b. GMS Biodiversity Conservation Corridors Investment Project in Champasak, Attapeu, and Xekong. Manila. Appendix 3: Natura Resources Sector-Lao PDR. 
support for conservation. Many of the most important biodiversity landscapes are vulnerable to increased development pressures leading to environmental degradation. For example, the fragmentation of the biodiversity-rich forest landscape in southern Lao PDR is impairing the provision of critical ecosystems that underpin local livelihoods. Investments in hydropower, transport, water, and agriculture are essential drivers in this regard.

37. Significant challenges to the present natural resource status exist and are largely caused by (i) changes in land use arising from population growth and rapid urbanization, infrastructure development, and large commercial forestry and agriculture concessions; (ii) poor forest management; (iii) hydropower development; (iv) shifting cultivation; (v) illegal hunting and poaching of wildlife species; (vi) mineral extraction; (vii) poor waste management; and (viii) floods and droughts and climate change. ${ }^{19}$

\section{Core Sector Issues, Causes, and Effects}

38. Key ANRRD sector and subsector problems and binding constraints are illustrated in the problem tree in the Appendix. The main sector problems are summarized as (i) low yields and production, (ii) unexploited potential for commercial production, (iii) unassured food safety and security, and (iv) reduced rural incomes and limited employment opportunities in the rural economy.

39. The ANRRD sector faces a range of physical, socioeconomic, and capacity challenges as follows:

(i) Physical constraints arise from the Lao PDR's geographic characteristics and climate such that: (a) rugged mountainous terrain reduces the amount of arable land and soil quality in many areas, and makes the provision of infrastructure expensive, particularly for transport; (b) limited availability of water during the dry season reduces the area of land that can be irrigated; (c) the dispersion of population with long travel times between settled areas, largely over hilly and mountainous terrain, increases travel costs, consequently limiting access to socioeconomic opportunities and services; and (d) vulnerability to climate instability and natural disasters, especially severe floods during the rainy season, exposes the country, its population, and cropland to catastrophic climate events.

(ii) Socioeconomic constraints include (a) a production base oriented to subsistence agriculture practiced by farmers who lack experience and basic technical, production, and market skills; (b) low productivity and low market prices and competition from neighboring countries; (c) underdeveloped value chains for cash crops and livestock; (d) limited access to agriculture inputs due to cost and logistical constraints; (e) limited access to irrigation facilities; (f) poor physical access that leads to postharvest losses and increased cost to move and process outputs;

19 Government of the Lao PDR, Ministry of Natural Resources and Environment. 2015. Natural Resources and Environment Strategy 2016-2025. Vientiane; Government of the Lao PDR, Ministry of Natural Resources and Environment and UNEP. 2012. Lao Environment Outlook 2012. Vientiane. 
(g) insecure land ownership and property rights, which reduces investment in, and protection of, land and water resources; and ( $h$ ) lack of access to financing for agriculture and agribusiness, which hampers investment and trade.

(iii) Capacity constraints include (a) poorly educated farmers with low levels of literacy and numeracy, who lack access to training on improved practices; (b) poorly defined and inconsistently applied policies, rules, and regulations, creating uncertainty in the market; (c) limited institutional capacity of government agencies to address infrastructure, trade, and economic challenges; (d) limited capacity of financial institutions to provide services in support of agriculture; (e) inefficient practices throughout the input and output value chains; ( $f$ ) the inability of farmers and agribusinesses to meet technical and sanitary and phytosanitary (SPS) standards, compromising food safety and reducing opportunities for export; and (g) shortfalls in government budgets needed to support the sector.

40. Sectors that have important impacts on ANRRD include transport, power, education, and finance. In addition, tourism has high potential to drive ANRRD development as pointed out in the 2017 ADB ASR for tourism. ${ }^{20}$ Linkages are through increased demand for agricultural products and the opportunity to develop short distance value addition chains for local produce to be supplied to tourist destinations. Tourism is also closely related and linked to natural resources conservation and environmental stability.

41. The constraints converge to cause the core sector problem of unrealized agricultural commercial potential with an eroding natural resource production base. The core sector problem leads to (i) low farming returns, (ii) suppressed value chain development, (iii) missed income opportunities, (iv) enduring poverty levels, and (iv) limited rural development options. The resulting core sector problem is low rural economic development and high rural poverty, public health risks, and exposure to climate instability.

42. The key ANRRD subsectors that ADB has or is likely to support are (i) irrigation and drainage, (ii) rural market infrastructure including rural access, (iii) agricultural production, (iv) agro-industry marketing and trade, (v) livestock, (vi) forestry, and (vii) land- and waterbased natural resources.

43. ADB ANRRD support has mostly been in the improvement of irrigation infrastructure consisting of irrigation headwork structures, canals, and drainage systems. Many irrigation schemes face shortages of water during the dry season, when streams in mountainous areas may run dry and major rivers may fall as much as 20 meters from their rainy season levels. In mountainous or hilly areas, this means that unless there is storage through reservoirs, there is little or no dry season flow. Most of the reservoirs constructed for the generation of hydroelectricity are not near the areas that could benefit from irrigation.

44. In riverine plains, water in the dry season must be pumped up to the level of the cultivated fields, requiring expenditures on power, adding to production costs. Yet, unless

ADB. 2017. Tourism Sector Assessment, Strategy, and Road Map for Cambodia, Lao Peoples' Democratic Republic, Myanmar, and Viet Nam (2016-2018). Manila. 
a dry season crop can be produced, the provision of irrigation infrastructure would likely be economically unviable. Given current and projected rice prices, the incremental production from wet season supplementary irrigation could well be insufficient to merit the investment required.

45. Operation and maintenance $(O \& M)$ is the major problem for irrigation sustainability. While minor repairs are borne by the water user groups (WUGs), major repairs are beyond their organizational and financial capacities and fall to the government, which also usually lacks the means to respond fully. Gravity systems, if not designed and constructed properly, are vulnerable to damage due to extreme storm flows and floods, which may also be beyond the WUGs' capacity to repair. Moreover, periodic upgrades that are needed over a 10-15year cycle, are expensive.

46. The government is supporting irrigation sustainability by building up WUG capacity to manage and operate the schemes. This has been successful to some extent as reflected in ADB project completion reports. Problems are noted to arise at the handover stage for the operation of the scheme without the transfer of full ownership from the government to the WUGs. Nonetheless, many schemes have been developed and continue to operate, providing reasonable grounds for expecting that irrigation investments can be successful.

47. The imperiled nature of the country's natural resources necessitates a focus on natural resources management. A key issue for ANRRD is the extent to which land continues to be converted to agriculture purposes especially in the form of commercial concessions. Regulating the way land is used is increasingly important.

48. The deterioration of watersheds, which is a major concern for irrigation, is caused by a combination of factors including (i) changes in land use and vegetative cover, (ii) agrochemical misuse, and (iii) climate change impacts. Issues associated with watershed conservation and management include (i) inadequately defined and, in some instances, contradictory policy and legal environment within natural resources conservation agencies; (ii) uncertain land ownership and tenure in much of the country; and (iii) lack of clarity on the responsibility for watershed protection among the Ministry of Natural Resources and Environment, Ministry of Agriculture and Forestry (MAF), and provincial authorities, all of which have limited capacity, workforce, and expertise. In 2017, the responsibility for all forest management and the poverty reduction program was given to the MAF. The MAF is restructuring its organization to respond to these new responsibilities. The deterioration of watersheds is increasingly a problem impacting irrigation.

49. Rural access continues to be a significant constraint for many rural households, particularly those found in the first and second poverty subgroups, and is a key component of the input and output agricultural value chains and market infrastructure. The problems facing rural access include (i) a dispersed population with long distances between settled areas and centers where services are available; (ii) the poor condition of the higher-order road network hampered by high construction costs, high O\&M costs, and inadequate O\&M arrangements; (iii) inappropriate rural road standards and specifications; and (iv) low traffic levels making it difficult to economically justify investment in rural roads, especially in the poorer and remoter regions of the country. 
50. The Lao PDR terrain, climate, and hydrology limit the choices for establishing sustainable approaches for rural access. As in neighboring Viet Nam, steep gradients, high rainfall, and flooding all cause unsealed roads to be unsustainable. ${ }^{21}$ Consequently, there are two feasible options for the design of rural access. The first option is basic access that involves spot improvements to remove the most critical obstacles to access. This approach is highly cost-effective and involves, for example, shaping the roadway to enable water runoff and the construction of cross-drainage structures (bridges, culverts, or causeways) and the paving of short sections of steep gradients. The second option is the construction of sealed paved roads with concrete surfaces, or bitumen-bound surfaces or other hard surfaces. This option is much more expensive but provides long-term service and lower O\&M costs.

51. ADB's Lao PDR country diagnostic study notes that the ANRRD sector is adversely affected by poor transport, which increases costs, reduces market access, and drives a larger differential between farm gate and retail prices. While trunk road infrastructure has improved during 2000-2018, the Lao PDR has some of the lowest levels of rural road coverage in developing Asia, which reduces connectivity between value chain segments. As an illustration, the Lao PDR has only about $200 \mathrm{~km}$ of road per 1,000 square $\mathrm{km}$ of land area, in comparison with Thailand with about $400 \mathrm{~km}$, and Viet Nam with about $500 \mathrm{~km}$. Reduced rural access limits access to services and markets and reduces the market value of outputs, hindering value chain development.

52. Power by rural electrification is an important facet of growth in the ANRRD sector. The availability and cost of dependable power supplies can play a critical role in activities such as irrigation pumping, food processing, and storage. It is also vital for commercialized livestock production. Outside the electricity grid, rural households rely on expensive off-grid power supply or have no electricity. Expensive energy hinders rural development and worsens the rural-urban income gap. In 2016, the government achieved 92\% electrification of households and aimed to achieve $95 \%$ electrification of households by 2020 . The government accords top priority to electrification of the northern provinces, where electrification rates remain low. As of 2015, only 73\% of households were electrified in Bokeo, Luang Namtha, and Phongsaly provinces compared with $99 \%$ in Vientiane.

53. The Lao PDR education system is producing average nationwide adult literacy rates of $50 \%$ for women and $67 \%$ for men; these figures are lower in rural and remote areas. $^{22}$ Inadequate education is a contributing factor for all poverty subgroups. Most farmers lack basic literacy and numeracy skills, which are essential to operate effectively in modern commercial agriculture. Agriculture and forestry research, knowledge, and practice development are underfunded in relation to their role in the economy. There are three major issues in the skills development for ANRRD: (i) the number of people being trained, (ii) the quality of training and relevance to modern commercial agriculture, and (iii) the delivery of training to those that need it.

21 J. Cook and P. G. Tuan. 2014. Improving Vietnam's Sustainability: Rural Road Pavement and Surfacing Design Options. Vietnam Transport Notes. Ha Noi: World Bank.

22 World Bank. Education Statistics. Country at a Glance-Lao PDR. http://datatopics.worldbank.org/education/country/ lao-pdr (accessed 9 December 2018). 
54. The Ministry of Education and Sports (MOES) has the overall responsibility for education quality assurance. The National University of Laos under the MOES has a faculty of agriculture, which offers study programs up to the master's degree level. ADB is providing support to the MOES to strengthen higher education, which will include establishing an agriculture center at Champasack University. ${ }^{23}$ The MOES offers agriculture-related training through technical and vocational education and training schools including Dongkhamxang Agriculture Technical School, Khammouane Technical-Vocational College, Savannakhet Technical and Vocational College, and Pakpasak Technical College. Table 5 highlights low enrollment rates in agriculture courses.

\section{Table 5: Number of Students in Agriculture Courses in State Schools (2016-2020)}

\begin{tabular}{|c|c|c|c|c|}
\hline \multirow[b]{2}{*}{ Sector } & \multicolumn{2}{|c|}{ No. of Students } & \multicolumn{2}{|c|}{ Percentage } \\
\hline & Total & Female & Total & Female \\
\hline Agriculture & 4,133 & 2,182 & 14.0 & 7.2 \\
\hline Other sectors & 26,088 & 10,150 & 86.0 & 33.6 \\
\hline Total & 30,221 & 12,332 & 100.0 & 40.8 \\
\hline
\end{tabular}

Source: Education and Sports Sector Development Plan, 2016-2020.

55. The lack of capacity to build knowledge and transfer skills challenges the MAF's training goal of strengthening the private sector in agriculture, rural, and forestry value chains. The objective of most students remains focused on becoming civil servants. The MAF provides ANRRD knowledge development, training, and capacity building through three main channels:

(i) National Agriculture and Forestry Research Institute. The institute is mandated to contribute to the Agricultural Development Strategy to 2025 and Vision to 2030 by researching development in agri-biodiversity sustainable use and conservation, productivity improvement, climate change adaptation and mitigation, and a supportive policy environment.

(ii) Five agricultural colleges. The colleges in the provinces of Champasak, Bolikhamxay, Luang Prabang, and Savannakhet, and in the village of Tha Ngon, Vientiane are the main providers of qualified government staff. ${ }^{24}$

(iii) Provincial and district agriculture and forestry offices. Extension services are provided through provincial and district agriculture and forestry offices. Operational costs of the services are also highly dependent on external financing.

23 ADB. 2016. Report and Recommendation of the President to the Board of Directors: Proposed Loan and Grant to the Lao People's Democratic Republic for the Second Strengthening Technical and Vocational Education and Training Project. Manila; and ADB. 2016b. Report and Recommendation of the President to the Board of Directors: Proposed Loan and Grant to the Lao People's Democratic Republic for the Second Strengthening Higher Education Project. Manila.

24 Government of the Lao PDR, MAF. 2008. Strategy for Reform in the Agriculture and Forestry Colleges towards 2020. Vientiane. 
56. Extending financial inclusion is essential in poverty alleviation. Access to a wider range of financial products and services is needed by a broad range of households and micro, small, and medium-sized enterprises..$^{25}$ The rural credit system in the Lao PDR is still underdeveloped in comparison with the demand, with limited lending for agriculture by commercial banks. In 2014, the share of agricultural loans of the total commercial bank portfolios was $9.5 \%$, which was almost lent entirely to larger agricultural ventures, rather than to farmers and small-scale enterprises. The Agricultural Promotion Bank and Nayobai Bank provide short- and medium-term loans to farmers and their groups at an interest rate between $5 \%$ and $9 \%$. Portfolio growth is restrained by cumbersome procedures that are not well adapted to agricultural activities and cause excessive delays in releasing funds.

57. Registered microfinance institutions (MFIs) in the Lao PDR are in the larger towns and do not yet adequately service rural areas. The latest comprehensive data on MFIs is from the end of 2013, when there were 11 deposit-taking MFIs with 78,000 members, 95\% of which are from the central region. There were also 24 non-deposit-taking MFIs with 25,000 members, and 18 savings and credit unions with 28,000 members. The total number of members in all registered MFIs was 132,000. Since then, the numbers have increased in all three categories, with the total number of institutions in 2017 exceeding 100. The key MFI clientele consists of salaried persons and traders. Many MFIs have developed appropriate systems and are expanding their operations to rural areas. As they lack lending capital, MFIs are often willing to borrow externally to expand their operations.

58. The primary informal organizations offering financial services are village funds, which are community-based operations that accept deposits from, and issue loans to, their members. Village funds provide a rapidly growing, mostly savings-driven capital base for investment in local agriculture production and trade. The village funds do not employ permanent staff and can function with low operational costs. At the end of 2014, there were 4,815 village funds with a total membership of 464,000, and an average of 102 members per village fund. The total village fund portfolio was $\$ 78.5$ million equivalent, with around 171,000 borrowers. The total savings were $\$ 65.5$ million equivalent, with the average savings per village fund of $\$ 16,000$.

59. Crosscutting themes include the following: First, women have a key role in agriculture production, and properly designed interventions in the ANRRD sector can benefit their lives. Better access to rural finance and knowledge will have positive impacts with gender-positive implications for bringing women into future rural businesses and marketing initiatives. Second, there is considerable concern about environmental degradation, particularly through foreign-sponsored land-based plantations. Third, the lack of documented land use rights creates three principal problems for agriculture: (i) transferable titles or land use certificates can serve as collateral and facilitate access to finance, and their absence makes agricultural lending more risky to financial institutions; (ii) the absence of documented ownership can mean that the government can reallocate land to other users, and that efficient land transfers among farmers may be risky; and (iii) the risk of land loss can mean that farmers are less likely to make long-term investments in productive potential.

25 United Nations Capital Development Fund. 2016. Lao PDR Financial Inclusion Roadmap 2016-2020: Draft. Vientiane. 


\section{Sector Strategy}

\section{A. Government Sector Strategy, Policy, and Plans}

60. The key policy framework for the ANRRD sector is set out in the following documents: (i) the 8th Five-Year National Socio-Economic Development Plan (2016-2020) (NSEDP8), and (ii) the Agricultural Development Strategy to 2025 and Vision to 2030. ${ }^{26}$ Both documents include a greater emphasis on encouraging international trade in non-rice agriculture products, the recognition of the need to improve and ensure food quality both for national consumption and export, the need to legalize land tenure, and a lesser emphasis on local food security via trade regulation.

61. The NSEDP8 average annual economic growth target is $8 \%$, with the direction to (i) maintain economic growth continuously, (ii) ensure sustainable and inclusive rural and human development, and (iii) expand growth in agriculture and forestry at 3.4\% annually (19\% of GDP by 2020). A principal policy goal is to reduce poverty among ethnic minority groups. Another key objective is to effectively and sustainably protect and use natural resources and the environment. The NSEDP8 uses an outcomes approach to development that emphasizes food and nutrition security, commercial production of agricultural commodities, and valueadded processing of agroforestry products.

62. The NSEDP8 emphasizes raising agricultural productivity as a development priority. In the short term, higher agricultural productivity will raise livelihoods for about 4.5 million people living on farms. In the longer term, increased productivity and mechanization would eventually lower the demand for agriculture labor, freeing up workers to move to more productive jobs in other sectors, resulting in the consolidation of landholdings. ${ }^{27}$ Within the NSEDP8, cross-border logistics will be developed to facilitate regional trade. Science and technology will be used to produce clean agriculture products for agro-processing industries.

63. The NSEDP8 proposes to supply water from irrigation projects for rice cultivation to 315,000 ha by developing the areas having a high potential for large-scale irrigated agriculture. Additional emphasis is placed on upgrading irrigation schemes in northern

Government of the Lao PDR, MAF. 2015. Agricultural Development Strategy to 2025 and Vision to 2030. Vientiane.

A. D'Hoore, S. Davading, and K. Phimmahasay. 2015. Lao Economic Monitor: Towards Restoring Macroeconomic Stability and Building Inclusive Growth. Lao PDR Economic Monitor. Washington, DC: World Bank Group. p. 40. 
provinces, with the objective of ensuring food security. Private investment is also sought for developing irrigated areas.

64. Regarding commercial commodities, the NSEDP8 emphasizes the following: (i) cultivation of coffee, vegetables, fruit trees, flowers, and cool-weather crops; (ii) reservoir fisheries and aquaculture; (iii) livestock rearing; and (iv) crops that are suitable to upland and mountainous agroecological conditions. The management of agricultural land will be improved, and the issuance of agricultural land titles to each family in focal areas will be completed by 2020 . Forest cover will be returned to $70 \%$ of the land area. Improved rural livelihood will be promoted through forest rehabilitation and protection of endangered wildlife. Investment projects will be subject to environmental and social monitoring.

65. The Agricultural Development Strategy to 2025 and Vision to 2030 aims to ensure national food security through sustainable agriculture that contributes to national economic growth, industrialization, and modernization. The strategy's overall targets include (i) increasing agricultural production, (ii) improving competitiveness in terms of quality, (iii) enforcing standards and regulations, and (iv) guaranteeing food security and safety through compliance with basic SPS standards. Agricultural production will thus contribute to (i) creating employment, (ii) generating income, (iii) decreasing disparities between urban and rural areas, and (iv) integrating rural development. New infrastructure will preserve culture, protect the environment, facilitate trade, utilize water resources efficiently, and contribute to stable ecosystems.

\section{B. ADB's Sector Support Program and Experience}

66. ADB's key ANRRD objective is to support sustainable modern agricultural commercialization, food security, and poverty reduction. Sustainable production necessitates a focus on natural resources management. Environmentally sustainable agricultural development and the protection of natural resources are important elements of both the government's NSEDP8 and ADB's Operational Plan for Agriculture and Natural Resources $(\mathrm{OPANR}){ }^{28}$

67. Over the past 5 years, ADB support in the ANRRD sector has consisted of additional financing for three ongoing investment projects and the funding of three new investment projects. ${ }^{29}$ In addition, ADB is providing technical assistance (TA) to build up capacity. The project activities include the following:

(i) Greater Mekong Subregion (GMS) East-West Economic Corridor Agriculture Infrastructure Sector Project supports the continuing transition of the East-West Economic Corridor into an inclusive economic growth corridor by stimulating

28 ADB. 2015. Operational Plan for Agriculture and Natural Resources: Promoting Sustainable Food Security in Asia and the Pacific in 2015-2020. Manila.

29 Two other projects had earlier received additional financing-the Nam Ngum River Basin Development Sector Project and the Smallholder Development Project. 
rural development, sustainable agriculture practices, and trade. ${ }^{30} \mathrm{It}$ is upgrading agriculture infrastructure, including irrigation and rural access roads, and is supporting capacity development in the farms to manage and use the agriculture infrastructure efficiently and effectively.

(ii) GMS Flood and Drought Risk Management and Mitigation Project is undertaking structural and nonstructural measures to prepare for and manage disaster risks linked to floods and droughts. ${ }^{31}$ Project interventions are (a) enhancing regional data, information, and knowledge base for flood and drought management; (b) developing water management infrastructure; and (c) preparing communities to manage disasters and adapt to climate change.

(iii) The Northern Smallholder Livestock Commercialization Project ${ }^{32}$ is (a) strengthening the capacities of smallholders and other livestock value chain actors as well as the support to the Northern Agriculture and Forestry College livestock training program, (b) strengthening livestock value chain infrastructure, (c) enhancing the capacity to access credit, and (d) supporting project management. In a parallel cofinancing arrangement, the International Fund for Agricultural Development (IFAD) is providing rural households access to sustainable and scalable rural financial services.

(iv) The additional financing for the GMS Biodiversity Conservation Corridors Project ${ }^{33}$ is supporting (a) policy, institutional, and human resource capacities for the United Nations Programme on Reducing Emissions from Deforestation and Forest Degradation; (b) agroforestry combined with livestock and crop production; and (c) use of noncommercial charcoal, afforestation, forest rehabilitation and protection, and monitoring of the carbon baseline.

(v) The additional financing for the Northern Rural Infrastructure Development Sector Project $^{34}$ is (a) improving productive rural infrastructure (PRI) including irrigation and rural access roads; (b) strengthening the productivity of completed subprojects; and (c) providing capacity building for national, provincial, and district agencies.

(vi) The additional financing for the Trade Facilitation: Improved Sanitary and Phytosanitary Handling in GMS Trade Project ${ }^{35}$ is facilitating greater trade in agriculture, food, and forestry products through improved SPS measures applicable to key trade requirements of the GMS. It is scaling up activities in the three main outputs: (a) surveillance and inspection for plant health, animal health, and food

30 ADB. 2013. Report and Recommendation of the President to the Board of Directors: Proposed Loan to the Lao People's Democratic Republic for the Greater Mekong Subregion East-West Economic Corridor Agriculture Infrastructure Sector Project. Manila.

31 ADB. 2012. Report and Recommendation of the President to the Board of Directors: Proposed Grant and Loan to the Lao People's Democratic Republic for the Greater Mekong Subregion Flood and Drought Risk Management and Mitigation Project. Manila.

32 ADB. 2014. Report and Recommendation of the President to the Board of Directors: Proposed Grant to the Lao People's Democratic Republic for the Northern Smallholder Livestock Commercialization Project. Manila.

33 ADB. 2014. Report and Recommendation of the President to the Board of Directors: Proposed Grant to the Lao People's Democratic Republic for the Additional Financing of the Greater Mekong Subregion Biodiversity Conservation Corridors Project. Manila.

34 ADB. 2017. Report and Recommendation of the President to the Board of Directors: Proposed Grant to the Lao People's Democratic Republic for the Additional Financing of the Northern Rural Infrastructure Development Sector Project. Manila.

35 ADB. 2017. Report and Recommendation of the President to the Board of Directors: Proposed Grant to the Lao People's Democratic Republic for the Additional Financing of the Trade Facilitation: Improved Sanitary and Phytosanitary Handling in Greater Mekong Subregion Trade Project. Manila. 
safety; (b) enhanced education levels and university training of SPS specialists; and (c) regional cooperation and harmonization for SPS measures and practices.

(vii) The TA Strengthening Access to Finance for Micro, Small, and Medium-Sized Enterprises (MSMEs) is strengthening MSMEs access to finance by addressing supply- and demand-side constraints as measured by the percentage increase in MSMEs using bank or MFI loans as a source of external finance. ${ }^{36}$ The outcome will be strengthened capacity of MSMEs to access formal finance for working capital through (a) a needs assessment of barriers in rice production, (b) MSMEs capacity development for business development services, and (c) awareness raising around existing financial service providers or funds in the respective market.

(viii) The regional TA GMS Core Agriculture Support Program Phase II (2011-2020), in which the Lao PDR participates, is addressing emerging challenges to agriculture development, specifically those linked with expanding cross-border trade in agrifood products, climate change adaption, and food and bioenergy security.

(ix) The regional TA GMS Core Environment Program, in which the Lao PDR participates, introduces environmental tools and processes, builds capacity for their use, and leverages their uptake in economic development. The focus is on environmental assessments, planning, piloting innovation, and monitoring. ${ }^{37}$

\section{Other Development Partner Support}

68. ADB coordinates with major bilateral and multilateral development partners in the ANRRD sector. The Sector Working Group on Agriculture and Rural Development, chaired by a deputy minister of the MAF, is the principal formal forum for this coordination to take place. In the ANRRD sector, ADB is coordinating with the following:

(i) Agence Française de Développement. It is promoting agroecological practices, the development of organic and fair-trade coffee production, and geographical indications (Cambodia, the Lao PDR, Thailand, and Viet Nam) by defining legislative frameworks and strengthening production sectors; rehabilitating infrastructure and setting up participatory irrigation management; and developing agricultural activities, livestock farming, and fishing.

(ii) European Commission. It is funding the Northern Uplands Development Programme with support from several bilateral and multilateral donors. In addition, the European Commission has projects supporting rice intensification, climate change adaptation, and rural water supply and sanitation.

(iii) Deutsche Gesellschaft für Internationale Zusammenarbeit (GIZ). It is providing support to strengthen rural financing village funds. $G I Z$ is also developing approaches for land titling. ADB is using the methods developed by GIZ in land use planning and land titling in project work.

ADB. 2014. Report and Recommendation of the President to the Board of Directors: Proposed Technical Assistance to the Lao People's Democratic Republic for Strengthening Access to Finance for Micro, Small, and Medium-Sized Enterprises. Manila.

37 GMS. Core Environment Program. http://www.gms-eoc.org/the-program. 
(iv) German development cooperation through KfW. It is working with the Bank of the Lao PDR on the Lao Access to Finance Fund to improve the provision of sustainable financial services and to establish a nationwide financial literacy strategy. KfW is supporting the Lao PDR's rural regions in extending and repairing roads, tracks, and bridges. Another focal area of KfW's work is tackling the country's increasing deforestation, thereby conserving biodiversity.

(v) Swiss Agency for Development and Cooperation. It is providing support to MAF's colleges through the nongovernment organization Helvetas to modernize and reorient agricultural education, developing skilled human resources to satisfy the needs of the modern market-based agricultural economy. ADB and Helvetas are cooperating at the Northern Agriculture and Forestry College in Luang Prabang to improve livestock instruction.

(vi) United Nations Capital Development Fund. It is supporting Fund for Inclusive Finance (sponsored by various donors). It also aims to improve the environment of microfinance and rural finance in the Lao PDR and to strengthen the capacity of financial institutions to supply their clients with adequate products and services meeting beneficiaries' needs and requirements.

(vii) United Nations Programme on Reducing Emissions from Deforestation and Forest Degradation. Its investment is being used along with the Forest Investment Program for ADB's GMS Biodiversity Conservation Corridors Project.

(viii) United Nations Development Programme. It has projects to (i) support agriculture resilience to climate change, and (ii) improve rural income activities and the quality of investments in extractive industries for poverty and environmental benefits.

(ix) Food and Agriculture Organization of the United Nations. The Lao PDR program of FAO is carried out through a series of projects oriented around four country outcomes: (a) fostering agricultural production and rural development; (b) improving food security and nutrition, with special focus on the most vulnerable; (c) protecting and enhancing forests and other ecosystems; and (d) improving capacity to respond to food and agricultural threats and emergencies and to climate change impacts. ${ }^{38}$

(x) International Fund for Agricultural Development. IFAD has been a cofinancier of several ADB projects in the sector and is cofinancing the Northern Smallholder Livestock Commercialization Project. The IFAD component is developing a national agriculture refinancing facility. IFAD and $\mathrm{KfW}$ are entering into a cooperation agreement to coordinate support to Lao Access to Finance Fund. In addition, IFAD is carrying out Strategic Support for Food Security and Nutrition Project; and the Southern Laos Food and Nutrition Security and Market Linkages Programme, which is closely coordinated with ADB's GMS East-West Economic Corridor Agriculture Infrastructure Sector Project.

(xi) World Bank. It is working with FAO and the MAF on increasing the productivity of rice on the seven large lowland plains in the Mekong Corridor.

38 FAO. 2010. FAO Regional Priority Framework 2010-2019: Towards a Food-Secure Asia and the Pacific. Bangkok. 
69. ADB experience and self-evaluation. Between 2000 and 2017, a total of six investment projects and two TA projects amounting to $\$ 117.7$ million ${ }^{39}$ had been completed (Table 6).

Table 6: Success Rating of Agriculture, Natural Resources, and Rural Development Completed Projects Approved since 2000

\begin{tabular}{|c|c|c|c|c|}
\hline Project & $\begin{array}{c}\text { Loan/ } \\
\text { Grant } \\
\text { Disbursed } \\
(\$ \text { million })^{\mathrm{a}}\end{array}$ & $\begin{array}{c}\text { Closing } \\
\text { Date }\end{array}$ & Subsector & Rating \\
\hline $\begin{array}{l}\text { Smallholder } \\
\text { Development } \\
\text { Project (including } \\
\text { additional } \\
\text { financing) }\end{array}$ & 16.7 & 2016 & $\begin{array}{c}\text { Rural } \\
\text { development- } \\
\text { multiple } \\
\text { activities }^{\mathrm{b}}\end{array}$ & Successful \\
\hline
\end{tabular}

\begin{tabular}{|c|c|c|c|c|}
\hline $\begin{array}{l}\text { Nam Ngum } \\
\text { River Basin } \\
\text { Development } \\
\text { Sector Project } \\
\text { (including } \\
\text { additional } \\
\text { financing) }\end{array}$ & 16.9 & 2016 & $\begin{array}{c}\text { Rural } \\
\text { development- } \\
\text { multiple } \\
\text { activities }\end{array}$ & Successful \\
\hline $\begin{array}{l}\text { Sustainable } \\
\text { Natural } \\
\text { Resources } \\
\text { Management }\end{array}$ & 35.0 & 2016 & $\begin{array}{c}\text { Rural } \\
\text { development- } \\
\text { multiple } \\
\text { activities }\end{array}$ & $\begin{array}{l}\text { Less than } \\
\text { successful }\end{array}$ \\
\hline
\end{tabular}

and Productivity

Enhancement

Project

\begin{tabular}{|c|c|c|c|c|}
\hline $\begin{array}{l}\text { Northern Region } \\
\text { Sustainable } \\
\text { Livelihoods } \\
\text { through Livestock } \\
\text { Development } \\
\text { Project }\end{array}$ & 16.4 & 2014 & $\begin{array}{c}\text { Livestock, rural } \\
\text { credit }^{c}\end{array}$ & $\begin{array}{l}\text { Less than } \\
\text { successful }\end{array}$ \\
\hline
\end{tabular}

The project was overambitious in setting targets for technology adoption that were beyond the capacity of traditional small livestock producers, most of whom are from relatively isolated ethnic groups. The project succeeded, however, in initiating a process of transformation to higher input and commercially oriented livestock management, and in providing a good starting point for ADB's next phase of support under the Northern Smallholder Livestock Commercialization Project. 
Table 6: continued

\begin{tabular}{|c|c|c|c|c|c|}
\hline Project & $\begin{array}{c}\text { Loan } / \\
\text { Grant } \\
\text { Disbursed } \\
(\$ \text { million })^{a}\end{array}$ & $\begin{array}{l}\text { Closing } \\
\text { Date }\end{array}$ & Subsector & Rating & Key Lessons Learned \\
\hline $\begin{array}{l}\text { Northern } \\
\text { Community- } \\
\text { Managed } \\
\text { Irrigation Sector } \\
\text { Project }\end{array}$ & 10.3 & 2011 & $\begin{array}{l}\text { Irrigation and } \\
\text { rural access }\end{array}$ & Successful & $\begin{array}{l}\text { Almost all communities are experienced } \\
\text { in managing their irrigation schemes and } \\
\text { cultivating irrigated rice, but they need } \\
\text { ongoing technical support and extension } \\
\text { outreach after the schemes have been } \\
\text { upgraded. }\end{array}$ \\
\hline $\begin{array}{l}\text { Decentralized } \\
\text { Irrigation } \\
\text { Development } \\
\text { and Management } \\
\text { Sector Project }\end{array}$ & 17.6 & 2010 & $\begin{array}{l}\text { Irrigation and } \\
\text { rural access }\end{array}$ & Successful & $\begin{array}{l}\text { Irrigation management transfer } \\
\text { programs can succeed if packaged } \\
\text { with interlinked interventions including } \\
\text { social, organizational, financial, } \\
\text { marketing, engineering, and agriculture } \\
\text { extension. }\end{array}$ \\
\hline
\end{tabular}

$\mathrm{ADB}=$ Asian Development Bank.

a This included cofinancing.

b These were not designed along subsector lines and contained a wide range of rural development activities.

c This was focused on the development of livestock production and related value chains.

Source: ADB.

70. Seven projects for a total cost of $\$ 235.9$ million are still ongoing with completion dates stretching out well into the 2020s as shown in Table 7.

71. The increased level of ADB funding and average project cost reflects growing confidence in the ability of the government to implement projects in the ANRRD sector. This is also reflected in the fact that, to date, 4 of the 11 projects have been deemed successful enough to merit additional financing. PRI (irrigation and rural access) projects show consistent success. One of the general rural development projects was deemed successful, but two were rated less than successful. The livestock project was rated less than successful; however, this was qualified in the lessons learned to indicate that further investment should proceed.

72. Two large TA projects have been completed since 2014 (Table 8). One involved support for rural infrastructure planning and implementation, while another involved general support in the water resources sector. Both were rated successful with the proviso regarding water resources TA projects that there should be a clear link with investment activities to ensure sustainability and stakeholder commitment. 


\section{Table 7: Ongoing Agriculture, Natural Resources, and Rural Development and Related Projects}

\begin{tabular}{|c|c|c|c|c|}
\hline Project & $\begin{array}{l}\text { ADB Loan } / \\
\text { Grant Amount } \\
(\$ \text { million })^{\mathrm{a}}\end{array}$ & Subsector & $\begin{array}{l}\text { Approval } \\
\text { Date }\end{array}$ & $\begin{array}{l}\text { Projected Closing } \\
\text { Date }\end{array}$ \\
\hline $\begin{array}{l}\text { Northern Smallholder Livestock } \\
\text { Commercialization Project }\end{array}$ & 21.0 & $\begin{array}{l}\text { Rural finance, rural } \\
\text { infrastructure, and } \\
\text { capacity building }\end{array}$ & 2015 & 2021 \\
\hline $\begin{array}{l}\text { Greater Mekong Subregion East- } \\
\text { West Economic Corridor Agriculture } \\
\text { Infrastructure Sector Project }\end{array}$ & 60.0 & $\begin{array}{l}\text { Irrigation, rural access, and } \\
\text { capacity building }\end{array}$ & 2013 & 2022 \\
\hline $\begin{array}{l}\text { Greater Mekong Subregion Flood } \\
\text { and Drought Risk Management and } \\
\text { Mitigation Project }\end{array}$ & 37.0 & $\begin{array}{l}\text { Capacity development, } \\
\text { irrigation, rural access, and } \\
\text { disaster management }\end{array}$ & 2013 & 2019 \\
\hline $\begin{array}{l}\text { Greater Mekong Subregion Biodiversity } \\
\text { Conservation Corridors Project } \\
\text { (including additional financing) }\end{array}$ & 32.8 & $\begin{array}{l}\text { Environmental } \\
\text { conservation and rural } \\
\text { development-multiple } \\
\text { activities }\end{array}$ & 2013 & 2019 \\
\hline $\begin{array}{l}\text { Northern Rural Infrastructure } \\
\text { Development Sector Project (including } \\
\text { additional financing) }\end{array}$ & 59.6 & $\begin{array}{l}\text { Irrigation and rural access, } \\
\text { knowledge, and practice } \\
\text { management }\end{array}$ & 2011 & 2022 \\
\hline $\begin{array}{l}\text { Trade Facilitation: Improved Sanitary } \\
\text { and Phytosanitary Handling in Greater } \\
\text { Mekong Subregion Trade Project } \\
\text { (including additional financing) }\end{array}$ & 24.0 & Capacity building & 2012 & 2020 \\
\hline $\begin{array}{l}\text { Technical Assistance: Strengthening } \\
\text { Access to Finance for Micro, Small, and } \\
\text { Medium-Sized Enterprises }\end{array}$ & 1.5 & $\begin{array}{l}\text { Finance sector } \\
\text { development }\end{array}$ & 2014 & 2018 \\
\hline
\end{tabular}

a This included cofinancing.

Source: Asian Development Bank.

Table 8: Success Rating of Recent Agriculture, Natural Resources, and Rural Development Completed Technical Assistance Projects

\begin{tabular}{|c|c|c|c|c|}
\hline Project & $\begin{array}{l}\text { TA Amount } \\
\text { Disbursed } \\
\text { (\$ million) }\end{array}$ & $\begin{array}{c}\text { Closing } \\
\text { Date }\end{array}$ & Rating & Key Lessons Learned \\
\hline $\begin{array}{l}\text { Supporting } \\
\text { Decentralized } \\
\text { Rural } \\
\text { Infrastructure } \\
\text { Development TA }\end{array}$ & 1.0 & 2016 & Successful & $\begin{array}{l}\text { The use of TA to provide additional capacity to an ongoing } \\
\text { investment project is effective when there are clearly } \\
\text { identified needs and constraints on the use of investment } \\
\text { resources to fill capacity gaps or develop capacity. A TA } \\
\text { project such as this one can ensure that for critical TA } \\
\text { inputs, highly qualified consultants are made available to } \\
\text { strengthen implementation. It is necessary to carefully } \\
\text { calibrate the TA inputs with those of the investment } \\
\text { project. The TA is important in carrying out studies and } \\
\text { assessments in supporting ANRRD sector development } \\
\text { and providing evidence to support decisions for future } \\
\text { ADB ANRRD sector investment. }\end{array}$ \\
\hline
\end{tabular}


Table 8: continued

\begin{tabular}{|c|c|c|c|c|}
\hline Project & $\begin{array}{l}\text { TA Amount } \\
\text { Disbursed } \\
\text { ( } \$ \text { million) }\end{array}$ & $\begin{array}{c}\text { Closing } \\
\text { Date }\end{array}$ & Rating & Key Lessons Learned \\
\hline $\begin{array}{l}\text { National } \\
\text { Integrated } \\
\text { Water Resources } \\
\text { Management } \\
\text { Support TA }\end{array}$ & 3.8 & 2016 & Successful & $\begin{array}{l}\text { As much as possible, institutional and technical capacity } \\
\text { building should be rooted in concrete actions and tied } \\
\text { to investment programs or policy-based lending. Clear } \\
\text { commitment from the key beneficiaries of the capacity } \\
\text { building is necessary. On TA administration, consulting } \\
\text { inputs should be efficiently packaged and integrated } \\
\text { instead of having separate consulting firms. }\end{array}$ \\
\hline
\end{tabular}

ADB = Asian Development Bank; ANRRD = Agriculture, Natural Resources, and Rural Development; TA = technical assistance.

Sources: ADB. 2016. Completion Report: National Integrated Water Resources Management Support Project in the Lao People's Democratic Republic. Manila; ADB. 2017. Completion Report: Supporting Decentralized Rural Infrastructure Development in the Lao People's Democratic Republic. Manila.

73. Political economy influences on progress. The experience of $A D B$ in some sectors has shown that attempting to bring about reforms either through project or policybased loans is unlikely to have a high degree of success in the Lao PDR. Political reforms and changes involve many diverse stakeholders and are difficult to undertake within a timeconstrained schedule. Some progress has been made in the past in overall water resources management, but this has been more of a technical than policy accomplishment. For the foreseeable future, ANRRD projects will need to be implemented within the existing political and policy environment.

74. Lessons learned. One of the lessons learned from ADB experience in the Lao PDR is that implementing agencies can implement multilateral-funded projects in the ANRRD sector, but that it is limited in extent and range (a small number of staff with a limited range of skills). Moreover, it takes time to build up the skills necessary to supervise and carry out project implementation, especially within the ADB governance and safeguard requirements. Thus, there is often a lag at the beginning of new projects, during which government personnel, contractors, and consultants need to upgrade their skills and expertise.

75. Consequently, success comes from building on experience where skills have already been learned. This accounts for the high degree of success among repeat projects and projects extended through additional financing. Another lesson is that there are now a series of models for implementation that can be successfully followed. These include gravity-based irrigation development in the northern mountains, larger pump and gravity schemes along the riverine plains in the center and south of the country, and rural access associated with irrigated and cultivated areas for both mobility and transport purposes. Benefit-cost analysis of irrigation investments in the Lao PDR has found that farm-scale irrigation investments performed better than large-scale investments. ${ }^{40}$ Less success has been attained with rural development multi-activity investments but with enough experience to provide some confidence for carefully selected interventions.

40 J. M. Kandulu and J. D. Connor. 2017. Improving the Effectiveness of Aid: An Evaluation of Prospective Mekong Irrigation Investments. International Journal of Water Resources Development. 33 (2). pp. 270-291. 
76. Irrigation leading to more intensive agriculture demands more labor, which will have natural resources conservation benefits. When the agricultural activity does not provide profits, there will be a reallocation of labor into the production of upland crops or other land uses often leading to land conversion and degradation. Priority should target improving the productivity of high-value resources through irrigation, improved technologies, and enhanced market access to counter this risk.

77. Implications for ADB's forward strategy. The subsectors, in which ADB has invested since 2004 and in which capacity has been improved, align closely with the priority investments set out in the recently approved OPANR. These are categorized into public PRI and non-PRI investments as follows:

(i) PRI investments consist mainly of irrigation, drainage, and rural access, presenting the following implications:

a. ADB-supported PRI projects have been consistently successful. They have been demonstrated to underpin increased agricultural production with improved market orientation.

b. ADB has a distinct competitive advantage in comparison with other development partners for PRI provision. PRI is expensive and requires the large-scale investment that few development partners have.

c. Well-targeted PRI investments provide quick and inclusive benefits to poorer areas. They complement ADB's support in other sectors such as transport, power, and tourism. They also complement smaller-scale investments by other development partners. Development partners and private investors can provide specialized inputs to ANRRD once PRI is established.

d. Capacity within the public and private sectors has been strengthened for the implementation of PRI projects.

e. Community PRI investments, particularly for irrigation where the communities hold ownership and management, are more sustainable than large irrigation schemes that require professional public-sector management.

f. PRI that integrates with direct market linkages for land use diversification has a substantial impact on rural household income, nutritional diversity, and the ability to retain and reward agriculture labor.

(ii) Non-PRI investments include support for trade, SPS and food safety, rural finance, rural waste management, livelihoods, commodity development, natural resource management, disaster risk and climate change adaptation, and capacity development. These investments

a. often have very high overhead costs such as management in comparison with actual investment, which needs to be controlled;

b. face substantial institutional barriers and capacity constraints, leading to reliance on external drivers for implementation; and

c. need to be carefully thought through and informed by ADB experiences as well as those of the other development partners (Opportunities to work with other specialized development partners for other subsectors should be explored to reduce risks). 


\section{ADB's Sector Forward Strategy}

78. The country partnership strategy (CPS) is aligned with the goals of the 8th Five-Year National Socio-Economic Development Plan (2016-2020) (NSEDP8) for more inclusive sustainable economic growth. The CPS identifies improving physical and human capital while protecting natural capital that is consistent with ADB's overall strategic priorities. The following goals also align with the necessary actions to assist three of the poverty subgroups:

(i) Infrastructure and private sector development to support employment and income generation, including objectives for developing infrastructure, strengthening private enterprises, and increasing productivity and promoting commercialization of agriculture. Improving agricultural productivity and promoting commercialization will create jobs for the poor, women, and ethnic minority groups in rural areas. ${ }^{41} \mathrm{ADB}$ will continue targeting areas with relatively higher levels of poverty in both the northern and southern regions. Projects will enhance farmers' access to PRI, increase the supply of nutritious food for domestic consumption, boost organic product exports, and promote employment led by women throughout the agriculture and rural value addition chains. ADB projects will (a) support PRI improvements in both irrigation and rural access, (b) promote agricultural expansion and diversification as an integral part of its projects, and (c) improve the enabling environment for agribusiness development.

(ii) Enhanced human development, including a component to build resilient human capital with relevant skills. The ANRRD sector will support skills transfer for decision-making and practice needed for sustainable commercialization. Special effort will be made to reach farmers. ADB's ANRRD program will work closely with other ADB departments responsible for education and improve agricultural and natural resource training and access to financial services. ANRRD projects will (a) increase farmer's access to land ownership, (b) improve campus infrastructure at MAF's agriculture and forestry colleges, and (c) include training needed for water user groups (WUGs) and agriculture trade and value chain development.

(iii) Sustainable natural resource management and climate resilience. The ANRRD sector will support sustainable natural resource management and climate resilience as a project component. This element of the strategy is reflected in the additional financing provided to the GMS Biodiversity Conservation Corridors Project approved in 2016. Climate change mitigation and adaptation actions in ANRRD sector projects will be selectively incorporated into ADB operations. An important area of support will be for watershed conservation. Disaster risk management will also be incorporated into ADB operations as appropriate. The approach taken to natural resources conservation is twofold: (a) all ANRRD projects will be designed to environmentally stable and climate-friendly standards, and (b) specific natural

41 The Sustainable Rural Infrastructure and Watershed Management Sector Project that is currently under design has estimated that support for dry season irrigated cropping over 400 ha is expected to generate an incremental hired labor demand of 58,000 days of employment valued at nearly $\$ 0.5$ million per annum, excluding the returns to the owner's household labor. 
resources conservation and climate change resilient interventions will continue to be included in ADB's activities.

79. Four strategic elements will support CPS goals. First, projects will be focused on the subsectors in which a proven capacity has already been built up through project experience. Second, lending will be consolidated into a smaller number of moderately large projects so that overheads can be managed within reasonable levels. Limiting the number of projects will avoid overstretching both government and ADB capacities to properly administer the project. Third, additional financing will be used to scale up well-performing projects to avoid delays associated with preparing and starting up new projects. Fourth, ADB will collaborate with development partners to deliver ANRRD priorities.

80. The bulk of ADB ANRRD operations will be in support of PRI. ADB will selectively support other subsectors as discussed above. The following are the rationale for prioritizing PRI: (i) PRI responds directly to key ANRRD sector constraints, (ii) ADB has a comparative advantage in delivering PRI investments, (iii) PRI is a priority in the NSEDP8, and (iv) PRI links with the priorities in ADB's OPANR.

81. Improvement in irrigation is the fastest and most direct means of not only increasing crop production for rice and others but also enabling diversification into higher-value crops demanded by the market. Producing surpluses is essential to develop input and output value chains. The provision of supplementary irrigation in the monsoon season can raise yields by as much as $50 \%$ (on average) by providing water during intermittent dry spells, enabling the use of higher-yielding varieties and providing sufficient assurance of successful harvests to allow investment in fertilizers and other inputs. Dry season irrigation can produce elevated rice yields or enable diversification according to market demand.

82. Irrigation subsector strengths and opportunities include (i) an experienced cadre of government officials within the government to supervise the implementation of irrigation development projects (on a modest scale); (ii) a policy in support of forming WUGs; (iii) upgraded schemes under prior projects of $\mathrm{ADB}$ and other donors, which still have further development potential; and (iv) a growing knowledge of and market for dry season cash crops that can generate higher levels of income than a traditional rice crop and thus help justify irrigation development financially and economically as well as fund irrigation scheme operation and maintenance (O\&M).

83 Priority will be given to modernizing irrigation schemes to proper engineered standards and to firming up O\&M arrangements to provide sustainability. ${ }^{42}$ Within irrigated command areas, ADB-financed projects will assist farmers to obtain land ownership titles. Farmers who own their land are more likely to nurture it and can more easily qualify for agricultural credit to upgrade operations.

84. There is an increasing awareness on the part of the government and other stakeholders of the importance of environmental stability and the conservation of watersheds.

42 ADB. 2011. Completion Report: Northern Community-Managed Irrigation Sector Project in the Lao People's Democratic Republic. Manila; and ADB. 2010. Completion Report: Decentralized Irrigation Development and Management Sector Project in the Lao People's Democratic Republic. Manila. 
This awareness is made more emphatic through the deficiencies in resource management, which have occurred lately. The conservation and improvement of watersheds are essential for sustainable irrigation and agricultural production and will be an integral part of the ADB support for PRI. The watershed measures will be designed through land use planning, which will assist communities to decide how best to protect the local environment and identify areas for irrigation and cultivation, settlement, community forest, and protected forests.

85. Strategically improving rural access in support of irrigated and cultivated areas will have a direct impact on connecting to external markets and providing an incentive to increase production. Rural access improvements are highly equitable for the rural population, as all residents of the area benefit from improved mobility and transport infrastructure. The level of investment in rural access needed to meet the nationwide requirement is beyond ADB's capacity to finance on a project basis, and beyond the government's capacity for implementation within a standard project period. Projects will need to be selected and designed to ensure that they meet rural access needs in priority areas, in conjunction with the irrigation modernization and market-oriented development.

86. Rural access subsector strengths and opportunities include (i) the development since 2000 of a relatively strong basic trunk road network including road linkages to the PRC and Viet Nam and bridges across the Mekong to Thailand, into which a rural road network can feed to link with markets for agricultural produce; and (ii) an increasing recognition among development planners and agencies at the national and provincial levels that the provision of rural access (and subsequent O\&M requirements) is a primary factor in improving rural livelihoods and stimulating agricultural production.

87. While there is an incentive to keep rural access construction costs low, it is also necessary to keep O\&M costs to a minimum and provide a road that will last under the country's tropical monsoonal climate. The environmental conditions in the Lao PDR make the use of inexpensive road surfaces such as gravel an inappropriate material. For improving rural access, ADB will support the two options of spot improvements and fully engineered roads. It should be noted that concrete (high initial costs but low maintenance costs and long life) and bituminous bound surfacing is now being used under ADB-supported rural infrastructure projects (footnotes 30 and 34).

88. Other subsectors are important for agricultural development for which ADB may carefully and selectively provide support, and these are as follows:

(i) Commodity and value chains. Close attention will be made to avoid negative market distortions. Support may include rural water supply, rural waste management, postharvest equipment, SPS systems, climate change adaption measures, and cross-border infrastructure.

(ii) Natural resource management. Priority will be protecting biodiversity and reducing risks from natural disasters and climate change. Integrating livelihood measures into natural resource management initiatives will be necessary. 
89. Thematically, ADB will support capacity development including measures to help farmers and agribusinesses modernize and expand operations throughout value chains for better commercial outcomes and in response to the growing effects of climate change. The weak technical capacities-within government agencies at the national, provincial, and district levels as well as among the country's farmers and rural population in generaland limited natural resource management capacity are a major constraint for improving agricultural productivity, climate change resilience, and preparedness for natural disasters. Continuous TA and training-loan or grant and international interaction with experts-is needed to bring knowledge and implementation capacities up to a level where project investments can be efficiently and effectively implemented. At the secondary education, this involves building critical skills such as literacy and numeracy, which will also support the overall capacity of those entering agriculture from secondary school.

90. Close coordination will be continued with the other sectors including the following:

(i) Education. ANRRD projects will include investments that complement those made by others in the education sector to increase the skills needed for farmers to operate commercially.

(ii) Transport. PRI investments will be targeted to easily access the transport network.

(iii) Rural finance. In the short term, ADB will rely on the efforts of development partners such as IFAD, GIZ, and KfW to move the subsector forward. As progress is made in the rural finance subsector, ADB will increase its direct support if and when viable rural finance mechanisms are established.

(iv) Tourism. Coordination with ADB's GMS tourism infrastructure projects will continue.

91. Thesubsectors in which ADB is likely to beactive are not envisaged to generate serious negative environmental impacts. Irrigation will normally be undertaken on land already being cultivated and will increasingly need to improve water use efficiency. Improved rural access will usually involve upgrading alignments. Rural finance will be important for agricultural development in areas such as livestock at a small-scale household level. Agricultural and rural value chain development will involve small- to medium-scale enterprises that do not have a significant environmental footprint. Capacity development will provide improved knowledge and practice with application to natural resources conservation.

92. Lending and non-lending program and resource needs. ADB's Lao PDR Country Operations Business Plan, 2018-2021 indicates the programs in the ANRRD sector (Table 9). The resources illustrated along with operational funding and appropriate staff resources will be required during the program period. 
Table 9: Current Agriculture, Natural Resources, and Rural Development Projects in the Country Operations Business Plan

\begin{tabular}{|c|c|c|c|}
\hline Projects/TA Projects & $\begin{array}{l}\text { Loan } / \\
\text { Grant/TA Amount } \\
(\$ \text { million })\end{array}$ & $\begin{array}{l}\text { Cofinancing } \\
\text { (\$ million) }\end{array}$ & $\begin{array}{l}\text { Proposed } \\
\text { Approval Date }\end{array}$ \\
\hline \multicolumn{4}{|l|}{ Projects } \\
\hline $\begin{array}{l}\text { Climate-Friendly Agribusiness Value } \\
\text { Chains Sector Project }\end{array}$ & 40.5 (grant) & TBD & 2018 \\
\hline $\begin{array}{l}\text { Northern Rural Infrastructure } \\
\text { Development Sector Project (additional } \\
\text { financing tranche 2) }\end{array}$ & $\begin{array}{l}30.0(\mathrm{COL}) \\
5.0 \text { (grant) }\end{array}$ & 50 & 2019 \\
\hline $\begin{array}{l}\text { GMS Flood and Drought Risk Management } \\
\text { and Mitigation Project (additional } \\
\text { financing) }\end{array}$ & $\begin{array}{l}35.0(\mathrm{COL}) \\
5.0 \text { (grant) }\end{array}$ & 0 & 2020 \\
\hline $\begin{array}{l}\text { GMS EWEC Agriculture Infrastructure } \\
\text { Sector Project (additional financing) }\end{array}$ & $\begin{array}{l}30.0 \text { (COL) } \\
5.0 \text { (grant) }\end{array}$ & 0 & 2022 \\
\hline \multicolumn{4}{|l|}{ TA Projects } \\
\hline $\begin{array}{l}\text { Southeast Asia Agriculture, Natural } \\
\text { Resources, and Rural Development Facility }\end{array}$ & $\begin{array}{l}\text { 3.0 TASF grant } \\
\text { 1.0 PRITF grant }\end{array}$ & 0 & 2018 \\
\hline $\begin{array}{l}\text { GMS Agriculture and Environment Service } \\
\text { Hub }\end{array}$ & $\begin{array}{l}\text { 1.8 TASF grant } \\
\text { 4.0 RCIF/DFID- } \\
\text { ARTCF grant }\end{array}$ & 0 & 2018 \\
\hline $\begin{array}{l}\text { Southeast Asia Agriculture, Natural } \\
\text { Resources, and Rural Development Facility } \\
\text { (additional financing) }\end{array}$ & 2.0 TASF grant & 0 & 2019 \\
\hline
\end{tabular}

ARTCF = Asia Regional Trade and Connectivity Fund, COL= concessional ordinary capital resources lending, DFID = Department for International Development of the United Kingdom, EWEC = East-West Economic Corridor, GMS = Greater Mekong Subregion, PRITF = Project Readiness Improvement Trust Fund, RCIF = Regional Cooperation and Integration Fund, TA = technical assistance, TASF = Technical Assistance Special Fund, TBD = to be determined.

Note: The pending Asian Development Bank (ADB) Lao PDR: Country Operations Business Plan (2019-2021) will bring changes, and this table will be updated in due course.

Source: ADB. 2017. Lao People's Democratic Republic: Country Operations and Business Plan (2018-2020). Manila.

93. Risks and assumptions. The CPS identifies two key interrelated risks concerning corruption and procurement. Specific risks facing the implementation of the ANRRD program include (i) weak policy implementation at all levels, (ii) ineffective and inconsistent enforcement of laws and regulations, (iii) hesitancy of agencies to manage public resources under their administrative responsibility, (iv) impulsive interventions in local markets, and (v) lack of inter-sector coordination in policy making and implementation.

94. The risks will be mitigated or reduced by (i) focusing on high-priority subsectors, (ii) investing in outputs that can be easily measured, (iii) the formulation and enforcement of agreements to protect and implement environmental policies, (iv) capacity building and training during project implementation, ( $v$ ) continuous monitoring of the policy and regulatory environment within which the project is being implemented, and (vi) technical assistance for initial planning and start-up activities. 


\section{Sector Road Map and Results Framework}

\section{Sector Road Map and Results Framework}

\begin{tabular}{cc} 
Country Sector Outcomes \\
\hline Outcomes & Indicators with \\
Targets and \\
Supported by ADB & Baselines
\end{tabular}

(i) Improved PRI and commercial agricultural expansion
Irrigated dry season areas increased to 315,000 ha by $2020(2015$ baseline: 103,000 ha)

Rice export increased to 0.60 million tons in 2020 (2012 baseline: 0.45 million tons)

\begin{tabular}{cc}
\multicolumn{2}{c}{ Country Sector Outputs } \\
\hline $\begin{array}{c}\text { Indicators with } \\
\text { Outputs Supported } \\
\text { by ADB }\end{array}$ & Incremental Targets \\
(Zero Baselines)
\end{tabular}

Irrigation rehabilitation and upgrading

\section{Rural road} improvement
Irrigated dry season areas increased by 212,000 ha by 2020 Rice export increased by 0.15 million tons by 2020

ADB Sector
Constraints on
Output Delivery

Limited and dispersed arable land resources

Limited dry season water supplies

Low levels of agricultural technology

Poorly developed institutional capacity
ADB Interventions

to Address

Constraints

Limited and dispersed arable land resources

Limited dry season water supplies

Low levels of agricultural technology

Poorly developed institutional capacity

\begin{tabular}{|c|c|c|c|c|c|}
\hline $\begin{array}{l}\text { (ii) Improved } \\
\text { watershed } \\
\text { conservation, } \\
\text { including } \\
\text { improved land use } \\
\text { management }\end{array}$ & $\begin{array}{l}400,000 \text { land titles } \\
\text { issued in rural and } \\
\text { urban areas during } \\
2016-2020\end{array}$ & $\begin{array}{l}\text { Watershed } \\
\text { planning and } \\
\text { rehabilitation }\end{array}$ & $\begin{array}{l}400,000 \text { land titles } \\
\text { issued in rural and } \\
\text { urban areas during } \\
2016-2020\end{array}$ & $\begin{array}{l}\text { Underdeveloped } \\
\text { markets } \\
\text { Restricted project } \\
\text { implementation } \\
\text { capacity } \\
\text { Limited } \\
\text { government } \\
\text { financial resources }\end{array}$ & $\begin{array}{l}\text { Pipelined Projects } \\
\text { with Estimated } \\
\text { Amounts: } \\
\text { GMS Climate- } \\
\text { Friendly } \\
\text { Agribusiness } \\
\text { Value Chains } \\
\text { Sector Project } \\
\text { (\$40.5 million) }\end{array}$ \\
\hline $\begin{array}{l}\text { (iii) Strengthened } \\
\text { PRI's climate } \\
\text { change resilience, } \\
\text { water quality } \\
\text { management, } \\
\text { and climate- } \\
\text { resilient agriculture } \\
\text { practices }\end{array}$ & $\begin{array}{l}\text { PRI schemes } \\
\text { modernized to } \\
\text { improve climate } \\
\text { resilience ( } 2017 \\
\text { baseline: not } \\
\text { applicable) }\end{array}$ & $\begin{array}{l}\text { Provision of } \\
\text { standards } \\
\text { for PRI and } \\
\text { conformity with } \\
\text { these standards } \\
\text { during project } \\
\text { implementation }\end{array}$ & $\begin{array}{l}\text { Climate-smart } \\
\text { agriculture and } \\
\text { agribusiness } \\
\text { strategy adopted } \\
\text { by } 2020\end{array}$ & $\begin{array}{l}\text { Underdeveloped } \\
\text { transport and } \\
\text { logistical system }\end{array}$ & $\begin{array}{l}\text { Sustainable Rural } \\
\text { Infrastructure } \\
\text { and Watershed } \\
\text { Management } \\
\text { Sector Project } \\
\text { (\$55.0 million) }\end{array}$ \\
\hline
\end{tabular}


Table: continued

\begin{tabular}{|c|c|c|c|c|c|}
\hline \multicolumn{2}{|c|}{ Country Sector Outcomes } & \multicolumn{2}{|c|}{ Country Sector Outputs } & \multicolumn{2}{|c|}{ ADB Sector Operations } \\
\hline $\begin{array}{c}\text { Outcomes } \\
\text { Supported by ADB }\end{array}$ & $\begin{array}{l}\text { Indicators with } \\
\text { Targets and } \\
\text { Baselines }\end{array}$ & $\begin{array}{l}\text { Outputs Supported } \\
\text { by ADB }\end{array}$ & $\begin{array}{l}\text { Indicators with } \\
\text { Incremental Targets } \\
\text { (Zero Baselines) }\end{array}$ & $\begin{array}{l}\text { Constraints on } \\
\text { Output Delivery }\end{array}$ & $\begin{array}{l}\text { ADB Interventions } \\
\text { to Address } \\
\text { Constraints }\end{array}$ \\
\hline & $\begin{array}{l}\text { Climate-smart } \\
\text { agriculture and } \\
\text { agribusiness } \\
\text { strategy adopted } \\
\text { by } 2020 \text { ( } 2016 \\
\text { baseline: not } \\
\text { applicable) }\end{array}$ & $\begin{array}{l}\text { Provision of } \\
\text { support to prepare } \\
\text { strategy }\end{array}$ & $\begin{array}{l}\text { Area under } \\
\text { climate-resilient } \\
\text { varieties of rice } \\
\text { and vegetables } \\
\text { increased by } 5,000 \\
\text { ha by } 2023\end{array}$ & $\begin{array}{l}\text { Lack of access to } \\
\text { credit } \\
\text { Deterioration of } \\
\text { the ecological } \\
\text { environment }\end{array}$ & $\begin{array}{l}\text { GMS East-West } \\
\text { Economic Corridor } \\
\text { Agriculture } \\
\text { Infrastructure } \\
\text { Sector Project } \\
\text { (additional } \\
\text { financing) } \\
\text { (\$62.0 million) }\end{array}$ \\
\hline & $\begin{array}{l}\text { Area under } \\
\text { climate-resilient } \\
\text { varieties of rice } \\
\text { and vegetables } \\
\text { increased by } 5,000 \\
\text { ha by } 2023\end{array}$ & $\begin{array}{l}\text { Support for } \\
\text { agricultural } \\
\text { research }\end{array}$ & & & $\begin{array}{l}\text { Ongoing Projects } \\
\text { with Approved } \\
\text { Amounts: } \\
\text { Northern } \\
\text { Smallholder } \\
\text { Livestock } \\
\text { Commercialization } \\
\text { Project } \\
\text { (\$21.0 million) } \\
\text { GMS East-West } \\
\text { Economic } \\
\text { Corridor } \\
\text { Agriculture } \\
\text { Infrastructure } \\
\text { Sector Project } \\
\text { (\$60.0 million) }\end{array}$ \\
\hline $\begin{array}{l}\text { (iv) Enhanced } \\
\text { forests and other } \\
\text { ecosystems, } \\
\text { with people less } \\
\text { vulnerable to } \\
\text { climate-related } \\
\text { events and } \\
\text { disasters }\end{array}$ & $\begin{array}{l}\text { Forest coverage } \\
\text { increased to } 70 \% \\
\text { by } 2020(2010 \\
\text { baseline: } 42 \%)\end{array}$ & $\begin{array}{l}\text { Agroforestry with } \\
\text { crops and livestock; } \\
\text { replanting; forest } \\
\text { patrols }\end{array}$ & $\begin{array}{l}\text { Agroforestry with } \\
\text { crops and livestock; } \\
\text { replanting; forest } \\
\text { patrols }\end{array}$ & & $\begin{array}{l}\text { GMS Flood and } \\
\text { Drought Risk } \\
\text { Management and } \\
\text { Mitigation Project } \\
\text { (\$37.0 million) } \\
\text { GMS Biodiversity } \\
\text { Conservation } \\
\text { Corridors Project } \\
\text { (including } \\
\text { additional } \\
\text { financing) } \\
\text { (\$20.0 million) } \\
\text { Northern Rural } \\
\text { Infrastructure } \\
\text { Development } \\
\text { Sector Project } \\
\text { (including } \\
\text { additional } \\
\text { financing) } \\
\text { (\$59.9 million) }\end{array}$ \\
\hline
\end{tabular}

$\mathrm{ADB}=$ Asian Development Bank, GMS = Greater Mekong Subregion, ha = hectare, $\mathrm{PRI}$ = productive rural infrastructure. Source: ADB estimates. 


\section{APPENDIX \\ SECTOR PROBLEM ANALYSIS}

\section{Figure A1: Agriculture, Natural Resources, and Rural Development Problem Tree}

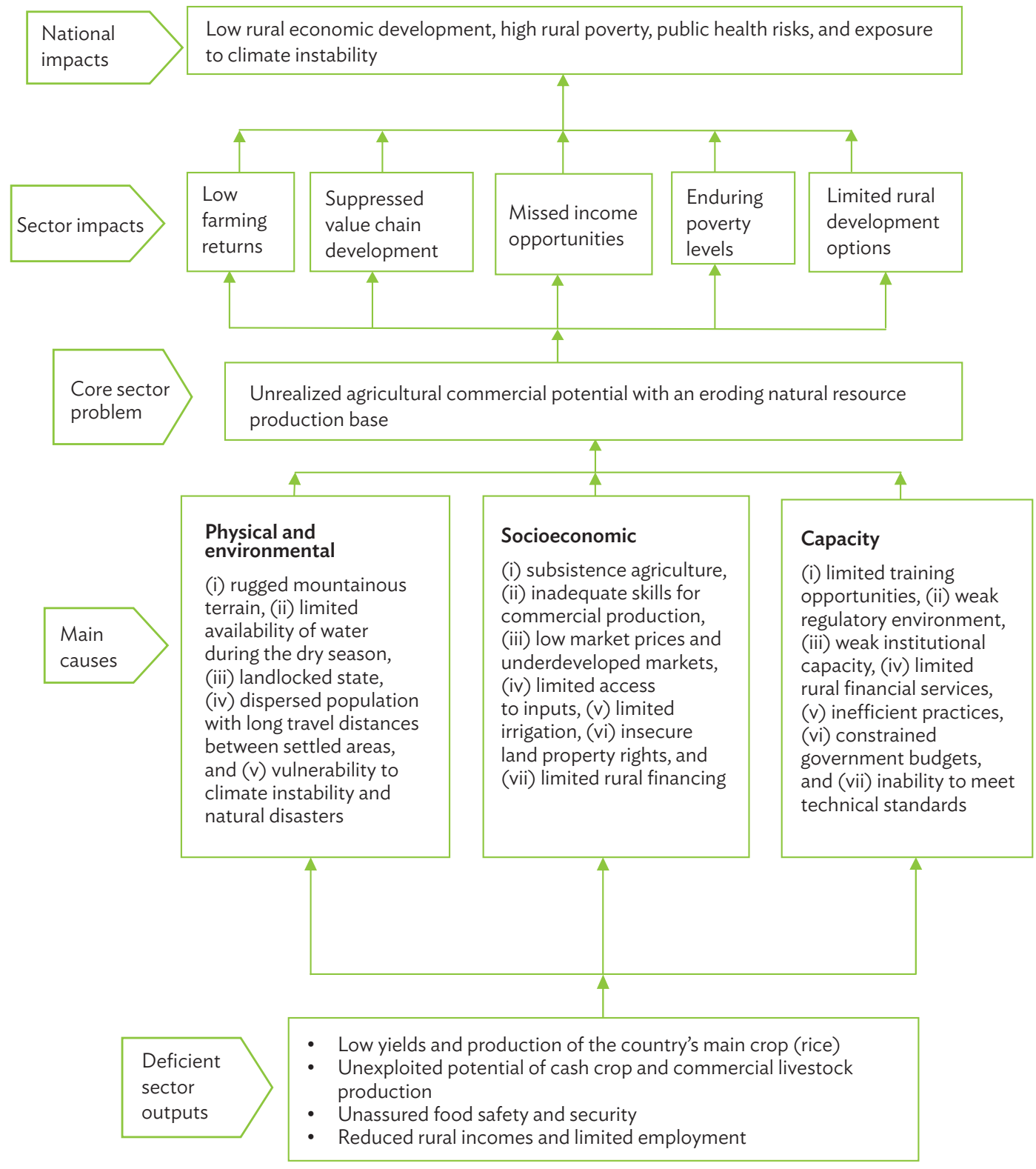




\section{Figure A2: Agriculture, Natural Resources, and Rural Development Objective Tree}

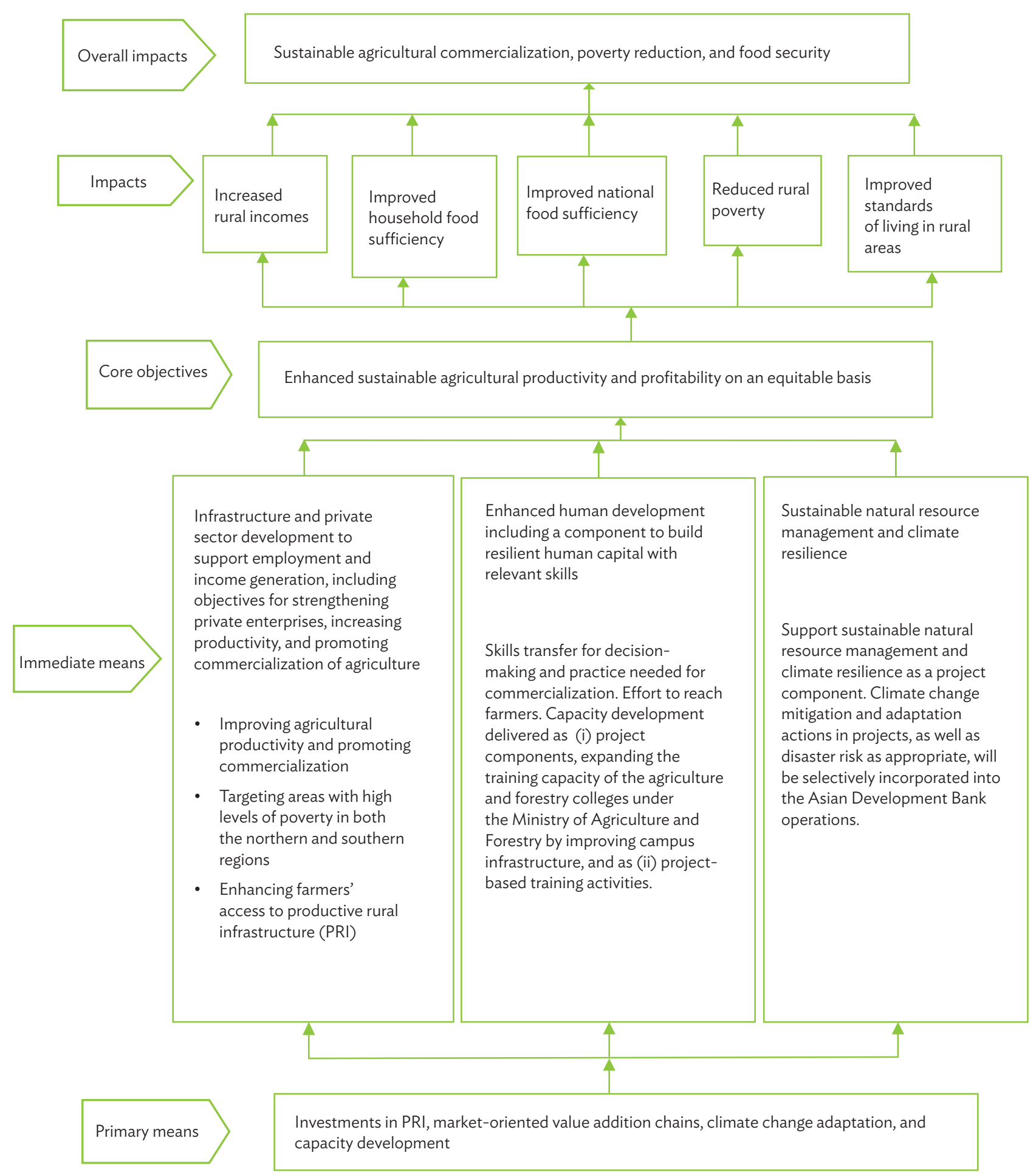

Source: Asian Development Bank. 


\section{Agriculture, Natural Resources, and Rural Development Sector Assessment, Strategy, and Road Map Lao People's Democratic Republic}

This publication explains the evaluation and strategic investment priorities of the Government of the Lao People's Democratic Republic and the Asian Development Bank (ADB) in the agriculture, natural resources, and rural development sector. It highlights sector performance, priority development constraints, government plans and strategy, other development partner support, and ADB's past experience and future sector strategy. The country partnership strategy of ADB is also discussed and updated as strategic developments and program changes occur. Other background information about the sector for ADB's investment and technical assistance operations are also provided.

\section{About the Asian Development Bank}

ADB is committed to achieving a prosperous, inclusive, resilient, and sustainable Asia and the Pacific, while sustaining its efforts to eradicate extreme poverty. Established in 1966, it is owned by 67 members48 from the region. Its main instruments for helping its developing member countries are policy dialogue, loans, equity investments, guarantees, grants, and technical assistance. 